\title{
Riga Municipal Physician Nicolaus Witte von Lilienau (1618-1688): His Medical Views at the Crossroads of Tradition and Changes in Medical Teaching during his Student Years at Dutch Universities in the $1640 \mathrm{~s}^{1}$
}

\author{
Arvo Tering \\ Tartu University Library \\ Struve 1, \\ Tartu 51009, Estonia \\ E-mail: arvotering@hot.ee
}

\begin{abstract}
The main subject of this article, Nicolaus Witte von Lilienau (16181688), a native of Riga was the city's municipal physician in 1652-1688. His studies at university proceeded during the 1640 s in Netherlands, particularly at Leiden but also at Utrecht and Franeker. The universities of Leiden and Utrecht, in particular, developed at that time into strongholds for the supporters of Harvey's theory of blood circulation and the philosophy of Descartes, from where those supporters spread the ideas that gradually found acceptance elsewhere as well. Witte was fortunate to have a closeup view of the fierce opposition between supporters and opponents of the philosophy of Descartes. Witte defended three disputations, two of which exercitii causa. The first was at Leiden on abdominal dropsy in 1645, the second was at Franeker on arthritis in 1647. He defended his doctoral dissertation on the plague at Leiden in 1648.
\end{abstract}

Witte's views on physiology were pioneering in all of his disputations. Under the apparent influence of his teacher Johannes Walaeus, Witte considered the teaching of blood circulation to be self-evident. Blood circulation was not the specific object of his research but used in interpreting the internal causes of illnesses. Witte's choice of sides was his dedication

\footnotetext{
This article has been completed with the support of the Estonian Scientific Competency Council Project SF $018004 s 08$ and the Estonian Science Foundation Grant Project no. 8938. The article would not have been completed without the assistance of Maria Luššsik, who kindly made available copies of seventeenthcentury disputations and secondary literature, or without the assistance of Anti Lääts, who transcribed early modern era publications into file formats suitable for blind researcher. Peeter Tammisto translated this article from Estonian into English.
} 
of his disputation of 1645 to Descartes and his closest friends and public supporters. This was a very bold move, considering the conditions of those times. Yet this probably did not derive so much from Witte's passion for Cartesian philosophy but rather from the fact that all those individuals were at the same time also supporters of the theory of blood circulation.

Witte had negative attitude towards authorities considered to be infallible, whether they be authors from antiquity or more recent authors. Thus he distanced himself from the supporters of both Galen and Paracelsus, considering them rival sects. Witte distanced himself in his disputations from both Galen's teaching of four bodily fluids, which was still widely accepted at that time, and the teaching of the movement of blood and of the liver as the centre for producing blood. Witte also denied the concepts of iatroastrology, iatromagic and iatrotheology associated primarily with the teachings of Paracelsus. Yet he did espouse the principle of three elements. And the learning of chemiatry.

Keywords: Disputations in the $17^{\text {th }}$ century, Harvey's theory of blood circulation, history of medicine in the early modern period, Paracelsus's concepts of medicine, philosophy of Descartes, reception of medical ideas, scientific method of investigation, studies in medicine at universities in the Netherlands, university of Leiden in the $17^{\text {th }}$ century

\section{Introduction}

Galen's humoral-pathological line of thinking that dominated throughout the Middle Ages, hand in hand with Aristotle's philosophy, gained new momentum by the middle of the $16^{\text {th }}$ century when Jean Fernel adapted it in 1558 into a system that corresponded to the new conditions that prevailed. The neo-Platonism that took root first of all in Italy in the $16^{\text {th }}$ century fostered the emergence of new medical trends that were largely inspired by Paracelsus (e.g., iatroastronomy, alchemy and iatrotheology), which were not without supporters among physicians even in the $17^{\text {th }}$ century. The empiricism of Hippocrates, the characteristic key words of which are autopsy, medical case histories and comparative observations, had a definite place in this thinking and, principally starting from the latter half of the $17^{\text {th }}$ century, gained wider appreciation. Yet the most important achievement in medicine was the very rapid development of physiology that draws on scientific methods of the natural sciences, particularly on experiments. The University of 
Padua provided impetus for this development in the $16^{\text {th }}$ and early $17^{\text {th }}$ centuries through the individual discoveries by its faculty members and alumnae that resulted in the theory of blood circulation, formulated by William Harvey in 1628. It was initially in a stage of incubation and did not attract any particular attention for some ten years. It was not until Descartes published his Discourse on Method in 1637 that Harvey's doctrine of blood circulation was brought into more widespread discussion, although Descartes himself was but an amateur in physiology (Fuchs, 1992, p. 144). Johan van Beverwijck (1594-1647), a physician in Dordrecht and a correspondence partner of Descartes, was one of the first Dutch doctors who ventured to defend Harvey's teaching of blood circulation in print in 1638 (Lindeboom, 1978, p. 19).

Discussions concerning Harvey's theory of blood circulation, which were started in the 1630s at the University of Leiden, but also at the University of Utrecht, turned out to be a touchstone for its acceptance, just as similar discussions starting in the 1640s proved to be for the acceptance of the philosophy of Descartes. It was just then that the University of Leiden was in the process of developing into Europe's most progressive institution of higher education with the highest international reputation. The university began attracting students, including young men interested in medicine, from throughout Europe, especially from English- and German-speaking regions and from the Scandinavian countries. The foundation for the University of Leiden's international appeal was laid already during the university's early years-confessional restrictions no longer applied to students studying at the faculties of philosophy, medicine or law since 1578 (Lindeboom, 1970, p. 202). This was an extraordinary step at that time on a European-wide scale. It was first and foremost the brighter medical students who had studied at the University of Leiden who transmitted the ideas of Harvey and Descartes throughout Europe. The young lecturer Franciscus le Boe Sylvius (1614-1672) was the first to introduce Harvey's blood circulation teachings at Leiden. Anatomy professor extraordinarius Johannes Walaeus (1604-1649) was initially sceptical of Harvey's claims. He decided to experimentally investigate the validity of Harvey's theory and conducted numerous vivisection experiments on animals in 1640. He sent the results obtained supporting the theory of blood circulation to his student Thomas Bartholinus (1616-1680), who had in the meantime gone to Italy. Bartholinus published them in 1641 in Leiden as appendices to the subsequent reprint of the anatomy handbook compiled by his father Caspar. The letters from Walaeus were again published in 1643 in the appendix to a reprint of Harvey's main work. As of 1645, however, they were published in expanded form (Schouten, 1974, p. 264). An English student Roger Drake defended his 
dissertation on the theory of blood circulation in Leiden under the supervision of Johannes Walaeus on 4 February 1640. It was vehemently attacked by the defenders of the Galen school of thought. The reprint of the masterpiece Exercitatio anatomica de motu cordis et sanguinis in animalibus in 1639 in Leiden no doubt promoted the expansion of the circle of people interested in Harvey's theory of blood circulation. Henricus Regius (1598-1679), who was professor at Utrecht since 1638, became an enthusiastic proponent of both the philosophy of Descartes and Harvey's theory of blood circulation in Utrecht. Both Regius and Cornelis van Hoghelande, a physician in Leiden, were the first to begin with the Cartesian tradition of blood circulation doctrine in Holland (Fuchs, 1992, p. 144). From this point onward, Harvey's theory of blood circulation spread from just those universities throughout Europe, particularly to England. Even more so, new physiological discoveries that followed the discovery of the blood circulation system provided reason for reinterpreting the functions of several of the body's organs. Each new discovery required as an autocatalytic effect the reinterpretation of hitherto existing knowledge where each discovery provided impetus for the next discovery. It was not until the last decade of the $17^{\text {th }}$ century that the new physiological paradigm had fallen into place once and for all as a scientific paradigm that had been proven from all perspectives. Of the numerous studies on this topic, the studies by Professor Karl Eduard Rothschuh (1953; 1957, pp. 605-612; 1969; 1978) at Munster, Swiss researcher Nikolaus Mani (1961, pp. 85-106; 1976, pp. 181-205) and Doctor Thomas Fuchs (1992) from Munich-Heidelberg stand out. What the reception was of the theory of blood circulation at the grass-root level among university medical students in those times remains a desideration of research. The Dutch medical historian Marius I. Lieburg has begun research in this direction with his study of the reception of the theory of blood circulation in doctoral dissertations by graduate medical students of German origin, defended at Leiden during the period from 1654 to 1688 (Lieburg, 1982, pp. 39-76). Lieburg, however, omitted the reception of the theory of blood circulation in the disputations of students at Leiden until 1654. The reason for this is that only random dissertations defended at Leiden before 1654 are preserved at the University of Leiden Library. On the other hand, a wealth of such dissertations can be found in London at the British Library and at the University of Edinburgh Library. The catalogues for these collections of dissertations, however, have only recently been compiled both in print and as online versions (Harskamp, 1997; Kelly, 2006). Now that these medical dissertations defended in the Netherlands are being made available, there is hope that pre-1654 disputations will also be researched. From the standpoint of blood circulation theories, disputations defended at universities and institutions 
of higher learning in German-speaking regions also merit closer study, especially Jena when it was presided over by Werner Rolfink and Paul Marquard Schlegel, and Helmstedt when it was presided over by Hermann Conring. It must be conceded, however, that the use of disputations as sources for the history of ideas has not at all been self-evident in German-speaking regions. It is only in the last few decades that an understanding of the value of disputations as sources has begun to develop (see Komorowski, 2011, pp. 60-65; Marti, 2011, pp. 293-314). Francesco Trevisani's (2011) very comprehensive treatment can be considered exemplary for the use of disputations in researching the ideas of physiology.

Swedish and Finnish historians of science have a long tradition of appreciation of disputations as historical sources. In connection with the theme of blood circulation, historian of learning and science Sten Lindroth's article on the disputation on blood circulation that Olof Rudbeck defended in 1652 in Uppsala is a worthy example (Lindroth, 1957). An article on the disputation defended in 1651 in Königsberg for earning the position of adjunct in the faculty of medicine there by Johannes Michel, the later personal physician of the Duke of Courland who had studied at Leiden in the 1640s, was recently published. This article examined the positive reception of Harvey's theory of blood circulation in Eastern Europe, in other words on the periphery of Europe (Tering, 2012, pp. 461-481). Michel's fellow student at the University of Leiden was to later become his long-time colleague in the Baltic area, Nicolaus Witte von Lilienau, who was the municipal physician for Riga, the administrative centre of Sweden's province of Livland. He defended at universities in the Netherlands three disputations, two of which were public disputations exercitii causa and the third of which was his doctoral thesis (Witte, 1645; 1647; 1648). Witte's disputation of 1645 has previously attracted attention due to his dedication of the work to Descartes and his friends, and due to his support for the theory of blood circulation (Tering, 1994, pp. 137-139; 2012, pp. 465, 481).

These disputations merit closer examination below. I will first attempt to describe the content of these disputations. The aim is to trace Witte's views regarding the theory of blood circulation as the central theme as well as his concepts deriving from Paracelsus. I will also strive to ascertain whether Witte can be considered an early supporter of the ideas of Descartes. Finally, the end of Ariadne's thread is offered for further research on what Witte's discourse with members of Europe's Republic of Letters was like at a time when he worked as a doctor and at the same time for the possible search for the fate of the heritage of his manuscripts. 


\section{Witte's educational background and career}

Before setting about analysing these disputations, let us take a closer look at Nicolaus Witte's educational background and subsequent career in order to better understand those disputations. The biography of the deceased presented in the parentation composed by Witte's relative Henning Witte (1688), who is known as a publisher of biographical reference books, provides the most reliable data concerning Witte's background. The biographical data presented in the lexicon of writers compiled by Recke and Napiersky (1832, p. 550) and Isidorus Brennsohn's lexicon of Livlands physicians (Brennsohn, 1905, p. 434) is also considerable. Nicolaus Witte von Lilienau was born on 6 December 1618 as the son of a merchant in Riga. In his last two years of study in the highest form at the Riga Gymnasium in 1639 and 1640, he presented two published disputations that were presided over by the school's rector Hermann Samson (Recke \& Napiersky, 1832, p. 30).

Witte was particularly fortunate to spend some ten years studying abroad. $\mathrm{He}$ first matriculated in September 1640 at the University of Rostock. At the very same time, Lorenz Bodocki (1606-1661), who was professor of rhetoric and history at the Riga Gymnasium from 1636-1640, took the position of professor of rhetoric at the University of Rostock for about the following twenty years. Thus he was Witte's former and future teacher. In 1642, Witte went to the Netherlands and enrolled in the University of Leiden on 23 December. In Leiden he was fortunate to communicate directly with the scholars on the front line of the current discussions on Harvey's theory of blood circulation and the teachings of Descartes. Just a few years before Witte's arrival in Leiden, professor extraordinarius of medicine Johannes Walaeus conducted a series of experiments there to verify Harvey's theory of blood circulation, the results of which he published as letters to his former student Thomas Bartholinus in Italy in several reprints. It was these experiments that would later provide Harvey himself with supporting evidence in his response to the critical attacks of Professor Jean Riolan from the University of Paris (Lindeboom, 1975, p. 281; Schouten, 1974, p. 278). Students of Walaeus spread the new theory of blood circulation to many European cities. During his time in Leiden Witte also visited the University of Utrecht in 1644, where the professor of medicine Henricus Regius was well known as propagator of theory of blood circulation and the ideas of Descartes.

In Leiden, Witte composed a disputation on dropsy in 1645 under the supervision of Walaeus. After defending his disputation, Witte undertook a journey through 
Germany. This can be deduced from the fact that he dedicated his second disputation, defended in Franeker on reasons of arthritis in 1647, among others to several scholars from Frankfurt-am-Main, to Andreas Kneuffeld, the personal physician of the King of Poland, and to Königsberg professor Johannes Löselius. At any rate, Witte was back in the Netherlands in the spring of 1646, matriculating at the University of Leiden again in May. Probably that same spring, Witte became acquainted with Thomas Bartholinus (1616-1680), who was about his age, the Danish scholar who went down in history by discovering lymphatic circulation and was later to become professor of medicine at Copenhagen. Bartholinus made a longer stop in Holland in the spring of 1646 on his way back to Denmark from Italy through Switzerland and France (he was in Amsterdam at least in February and in Leiden at least in April) (Helk, 1977, p. 162). Bartholinus was one of the persons to whom Witte dedicated his disputation of 1647. Unfortunately, their subsequent relations cannot be traced because letters from Witte are not among the published correspondence of Bartholinus, but Bartholinus's letters to Witte are not known to have survived (see Witte, 1688, p. 5; Bartholinus, 1663, vol. I-IV). That same autumn, in 1646, the atmosphere at Leiden became very volatile: on 18 September, professors of the Faculty of Philosophy Jakob Golius and Adriaan Heereboord supported the Cartesian method of doubt during Paul Biman's defence of his dissertation. This led to a far-reaching scandal that culminated with a ban in 1647 on speaking in favour or against the philosophy of Descartes (Verbeek, 1992, pp. 38-40). Three weeks later, on 8 October, Witte enrolled in the University of Franeker where Cartesianism had not yet spread. Yet Aristotle had never been held in esteem at the Faculty of Philosophy of University of Franeker either. Johannes Phocylides Holwarda (1618-1651), professor extraordinarious of logic as of 1639 and professor ordinarious of logic as of 1647, preferred the atomistic views of Pierre Gassendi.

It remains unresolved whether Witte's departure from Leiden was to escape from the controversy over Cartesianism. Perhaps Hermann Meiners, Witte's friend from his time at the Riga Gymnasium who had by then studied law at Franeker for a full year already, provided the impetus for Witte to go to Franeker. Witte presented a disputation on arthritis presided over by Johannes Antonides van der Linden in 1647 at Franeker. Professor van der Linden disliked the teachings of Descartes at that time, yet he was in favour of the doctrine of blood circulation. He did not support it as Harvey's theory but, as an enthusiastic admirer and populariser of Hippocrates, he claimed that even the idea of the teachings of blood circulation originated from Hippocrates (Lindeboom, 1985, pp. 364, 369). 
By the summer of 1648 at the latest, Witte was back at the University of Leiden. The same year the supervisor of his disputation of 1645, Johannes Walaeus, had become professor ordinarius of medicine. In November that same year, Witte defended his doctoral dissertation on the plague. Thus Witte had produced disputations on three occasions during his stay in the Netherlands, two times as public works exercitii causa and the third time as a doctoral dissertation. This procedure was also compulsory for doctoral candidates at the University of Leiden: one had to first defend two disputations exercitii causa. These public disputations were meant to provide experience in speaking in public to an audience about what the doctoral candidate had learned before the candidate was allowed to defend his degree dissertation (Lindeboom, 1970, p. 204; Schouten, 1974 , p. 259). As a general rule, these practice works were not published since doctoral candidates would not have been able to pay the costs of publication. The fact that Witte published them is rather exceptional. Apparently many people from among those to whom he dedicated his works helped Witte to cover the costs of publishing his disputations. Witte's doctoral dissertation, however, was dedicated to the Council of the City of Riga and the municipal council probably at least partially covered the costs of publishing the dissertation. This dedication was also an explicit signal that Witte could be considered a candidate for the job of municipal physician for Riga.

Witte left Leiden in December 1649. He planned to journey back home via Stockholm, where he by all means wished to participate in the coronation celebrations of the Queen of Sweden. Witte, however, was ill in Amsterdam for an extended period of time (Witte's letter from Amsterdam to Nicolaus Heinsius dated 30 April 1650; see UBL, 1650), yet he still made it to the coronation celebrations, where guests from all over Europe had gathered. Witte remained in Stockholm in 1651 as well, from where he journeyed onward home to Riga, from where he planned to journey to Lübeck in the autumn of that year and from there to probably travel onward in Germany and France. In any case, Witte was definitely back in Riga in 1652, when he took up the position of second municipal physician and married Gertrud, the daughter of first municipal physician of Riga Johann von Höveln. In 1663, Witte rose to the position of first municipal physician. A few years later, Witte also became the personal physician of the King of Sweden, for which reason he often had to travel to Stockholm. In 1666, Witte and his family were promoted to the ranks of the Swedish nobility under the name of Witte von Lilienau for his work in fighting the plague and for putting his own money into the fight against the plague. Thus Nicolaus Witte had achieved the highest position in the social hierarchy that was at all 
possible in the prosperous centre/core/capital of a Swedish province. Previously his father-in-law Johann von Höveln had the highest social status. Along with his position as Riga's municipal physician, he was also the personal physician of the Duke of Courland. About the last ten years of Witte's life, however, can be considered tragic: within a short period of time, he lost his wife, his son, who had promising talents, and his two daughters. This is all the more tragic since an economically prosperous doctor with notable knowledge and high social position was unable to do anything to save the members of his own family from the Grim Reaper. Nicolaus Witte himself died on 5 January 1688.

\section{Nicolaus Witte's disputations and their subject matter}

Witte ventured to consider serious diseases in all three disputations: dropsy, which accompanies either a tumour, serious heart disease or kidney disease; arthritis, which causes a person suffering from the disease excruciating pain; and the plague, from which only a minority of victims recovered. The circle of authors that Witte used in his disputations cannot be determined because, unfortunately, Witte does not mention specific works or their authors. Witte's disputations of 1645 and 1647 were polemical as in fear of getting himself into too much hot water he left the authors that were subject to attack anonymous. They were very well known for readers of that time but unfortunately remain anonymous to researchers operating centuries later. Disputations exercitii causa were far from being always written by the student. But these works were written entirely by Witte himself.

In his first disputation in 1645, where Johannes Walaeus presided over its defence, Witte (1645) examines abdominal dropsy. Nowadays, dropsy is considered to be the accumulation of liquid containing little protein that has emanated from blood veins in tissues beneath the skin and in body cavities, especially in the stomach cavity. This mostly accompanies serious heart and kidney disease and cirrhosis of the liver. Witte's positions on the matter do not differ essentially from this view. In his opinion, hydrops develops from serous bodily fluid originating from food and drink. Serum mixes with blood mass, yet, if the blood vessels are clogged or if obstacles develop in certain organs of the body, the serum segregates from the blood and independently seeks a way out of the blood vessels that are more subtle than blood. Blockages can arise from tumours, for example, especially in the spleen, the liver, the Aselli glands or the kidneys. 
It can also be caused by deficiency or excessive intensity in warming the blood in the heart or by an excessive supply of serum in the organism that the body is incapable of excreting through perspiration or urination. Serum has four tasks: first of all, it helps to digest food in the stomach and to transport chyle onward in as fluid a state as possible; secondly it keeps the blood as fluid as possible as it moves through capillaries to all parts of the body; thirdly, serum functions as lubricating fluid to keep joints mobile; and fourthly, serum operates as a solvent of salts moving in the blood veins, a softener of the sharp spikes of salt acrimonies that helps to excrete salts by way of the urinary tracts and the bladder.

Witte argues against the position according to which nature (natura) ensures that bodily fluid has the intelligence to move to the afflicted area of the organism induced by the warmth and pain that has arisen there. Could this not be considered Witte's presentiment of lymphatic circulation?

Witte's disputation occupies a very important place as a witness and participant in the crossroads of one of the more important early modern changes in paradigm of intellectual history. Namely, Georg Siegfried Freudenhammer from Silesia had without presiding defended his doctoral dissertation on dropsy at Leiden on 19 May 1645. This dissertation relied on the teachings of Galen. Freudenhammer based his dissertation on the idea that as an unnatural tumour, dropsy originates from the immoderateness of cold in the liver. ${ }^{2}$ In other words, all causes that lead to the immoderateness of cold in the liver and can cause deviation from inherent warmth are categorised as procatarctic causes. ${ }^{3}$ It is possible that this very same dissertation provided the decisive incentive for Witte to compose the polemical disputation he defended two months later. Witte ironically said about the discussion of Galen's reasons for dropsy that in his opinion, until that time, not a single author that he had happened to read had succeeded in satisfactorily proving anything. That is, authors mostly blame immoderateness of cold in the liver and believe that this brings the issue to a close even though they have neglected to delve deeper into the matter independently. ${ }^{4}$

Witte considers the causes and nature of arthritis in his second disputation exercitii causa, defended in 1647 in Franeker and presided over by Johannes Antonides van der Linden (Witte, 1647). In Witte's opinion, arthritis is sharp

2 Est autem hydrops, tumor praeternaturalis, vel partis cuiuspiam, vel etiam totius, aspectu non subterfugiens, ab humore flatuque distendente excitatus, ex frigida hepatis Intemperie prognatus. (Freudenhammer, 1645, Thesis 2).

3 Procartarcticis causis annumerantur omnia illa, hepati frigidam imprimere intemperiem, et calorem innatum dissolvere possunt (Freudenhammer, 1645, Thesis 8).

4 autorum, quos mihi legere contingit, animo meo satis facere potuit. Plerique enim, insontis hepatis frigidam intemperiem accusantes, egregie se rem confecisse putant, nihil ultra satagentes (Witte, 1645, Thesis 39). 
pain that proceeds intermittently in sensitive parts of the areas around joints (in membranes but also in membraneous ligaments and also in nerves, tendons and muscle membranes). Broadly speaking, the direct cause of the disease is serum containing three different substances: first, watery bodily fluid originating from drink and from watery food that gives it its fluidity; second, salts and their acrimonies dissolved in watery bodily fluid; third, residue of excrements named tartarus together with salt dissolved in watery bodily fluid. Serum also flows to the joints through the blood veins. The watery part of serum evaporates in the continuous warmth of the body through the barely noticeable breathing of the skin, but the part consisting of tartarus stays put.

Caustic salt acrimonies that sting and tear at the joints cause arthritic pain. Salt acrimonies from very stinging and subtle salt also cause other illnesses accompanied by stinging pains. Distensions caused by quantities of serum that have streamed in through the blood veins in places that have already been damaged by sharp, penetrating salts increase the sufferings of pain in joints.

Witte explains the causal nature of arthritis as follows. The pressure of serum on joints derives from the effect of actio pulsionis emanating from the heart. Namely, the thinning and expansion of the spirituous corpuscles of the blood take place in the heat caused by the boiling of blood mass. Serum is thus no longer able to remain in the veins and requires more space but it cannot enter the veins right away by anastomosis through the dense and taut arteries. The serum rushes onward and finally finds a place to discharge itself. Part of the serum penetrates joints in the periphery of the body. Warmth also causes greater movement of salt particles circulating with the blood. Salt acrimonies cause blockages of blood veins, ulcers and other illnesses. In the case of arthritis, salt particles move in the body together with the blood, causing sharp pains in joints.

Witte, however, makes an interesting observation: the amount of tartarus entering the organism depends on how much tartaric salts are deposited. Thus wine causes a double risk of arthritis. Namely, wine increases both the amount of serum and of tartaric salts in the organism. For this reason, podagra is altogether endemic in southern regions where the culture of wine is prevalent but it is very rarely found in northern lands.

Witte's disputation relies entirely on the teaching of the principle of three elements deriving from Paracelsus. While Galen's teaching of four bodily fluids considered rheumatic diseases to be the spasmodic flows of corrupted bodily fluid that form rheumatic nodes in joints as they densify, according to Paracelsus, 
chemical products of decomposition are deposited in the kidneys and joints analogously to tartar (tartarus) in wine (Enzyklopädie Medizingeschichte, 2005, p. 492). It is not clear what motivated Witte to write up his study on arthritis. We cannot, however, ignore the circumstance that one of the persons to whom his disputation of 1647 was dedicated was Johan Lösel (1607-1655), professor of medicine at the University of Königsberg, whom Witte may have met during his trip through Germany. Lösel had published a paper on podagra at Leiden in 1639 (Losell, 1639). Could Lösel have possibly inspired Witte to dispute on the theme of arthritis? Let it be pointed out in the interest of further research that in that same year of 1647, the future Cartesian Professor Johannes De Raei at the University of Leiden had defended his doctoral dissertation at Leiden on the same theme of arthritis (Harskamp, 1997, No. 185). He had come to Leiden in 1643 , at about the same time as Witte.

The dissertation that Witte presented as his doctoral thesis in 1648 (Witte, 1648) is thus far the only known dissertation specifically dedicated to the plague by a physician that worked in the Baltic provinces in the Early Modern era.

Witte says that the plague is the most virulent, extremely lethal epidemic disease. Three conditions are required for infection by the plague:

1) The strength of the effective force of the poison and its subtlety that enables it to penetrate everywhere;

2) A brief incubation period;

3) Distance of direct contact with infected persons.

Falling ill nevertheless depends on the predisposition and the strength of the capacity for resistance of the organism that receives the poison to hinder the intrusion of the poison that causes plague. An epidemic contagious disease has to have a common cause that encompasses a large area. This cause has been considered to be food and air, either one or the other, or both of them together.

In Witte's opinion, spoiled food cannot be the main cause of the plague because different peoples have different eating habits and different foods are consumed even within one and the same region. It is more likely that the air gives rise to and spreads the plague since all people breathe it in simultaneously. The pollution of air may occur either from the heavens above or from the ground. The warmth and light that come from above do not in any case pollute the air to the extent that it would become poisonous. The air is spoiled by those vapours that come 
forth from within the ground. They are either watery or sulphuric. Sulphur and water are two evanescent principles that rise in reaction to warmth. Rain, clouds, snow, etc. are formed from watery vapours. On the other hand, meteors, thunder, etc. arise from sulphuric fire. They are joined by evanescent salts. On top of that, the air is infected by the smoke of burning things: also by vapours, canals of waste water, caves, lakes, bogs, the corpses of dead animals and other matter that rises. The seeds of the plague come from the poisonous vapours that rise up into the air out of the ground.

Witte, however, rules out vapours arising from backwaters, corpses and sewage pipes as causes of the plague. Such vapours do indeed cause many different kinds of illnesses, but the plague arises not from putrescent but rather from poisonous vapours that infect the air. Poisons may be both of vegetal or animal origin but only mineral poisons that have spread far and wide in the depths of the earth bring about the plague. Poisonings are common in metal mines. The most potent of the poisonous minerals that poison the air with their detrimental vapour are arsenic and mercury. The smoke, in other words, the vapour of each is particularly dangerous.

Arsenic is found in ores in the form of many different kinds of compounds. As such they are indeed exceedingly poisonous but not as poison causing plague. Arsenic is found in almost all metal mines, evaporating from the heat of the underground fire (at the earth's core). Yet when metal is smelted, arsenic evaporates into the air together with smoke from the furnace and sticks everywhere.

The warmth of the fire at the earth's core that lifts arsenic up into the air can also stir up other poisons, particularly mercury. The poison is bonded with other evaporating substances and sublimates, dissolves or is deposited as it reacts with whatever type of salt, acquiring a corrosive nature. Arsenic spreads and also dissipates by way of the air like the sparsest and most subtle pneuma. We are incapable of perceiving with our senses arsenic poison spread out by the air. It penetrates the blood mass unnoticed, which then carries the poison to all parts of the body. If the infected blood reaches the heart, however, it damages the heart.

In preventive terms, it would be most important to prevent the plague altogether. This consists of either removing or diverting the plague-infected air so that it would not enter the body or at least so that it would not damage the body. It is easier to keep the plague away than to fend it off once it has gained entrance. There are two ways to prevent the plague: the first is to remove the causes of plague, which is not at all always within one's means. This is why it is necessary to 
try to prevent the plague-inducing poison from entering the organism. Poisoned air is removed by all possible means that manage to vigorously dissipate and move the air.

Air is ventilated and moved in order to dissipate atoms of poisoned air. Wind and fire are the most suitable for this purpose. What takes place in the air outside can also be replicated indoors. In Witte's opinion, the use of Heron's steam engine (Aeolipila) would best meet preventive objectives. It produces billows of vapour with a great roar and sudden gusts of wind and could sufficiently move and dissipate air in rooms. Added acidic medicines, particularly vapours containing acetic acid, would protect the body itself with a defensive wall against plagueinducing poison.

It is said that already Hippocrates had recommended directing air through fire and this has justified itself through the centuries. Namely, fires dissipate poisonous air or do an excellent job of using it up. Sticky tar and bitumen absorb atoms of arsenic as they burn and vaporise the poisonous air. They trap those atoms and thus return cleaned air. The smoking of other greasy and oily substances also appears to gather poisonous air together well. Witte is of the opinion that beyond wind and open fires, everything that moves and dissipates the air in whatever way is useful, like for instance the sound of bells, loud bangs, etc., even though such means are far weaker in protecting against the plague than wind and fire.

Since it is not always possible to clean poisonous air, the second preventive measure must be used: keeping plague-inducing air away from the body as much as possible. Since air enters the emptier vessels of the body more than filled vessels, it therefore appears that people should eat moderately and avoid excessive movement, activity and perspiration, since blood veins expand from the excess warmth caused by the motion of the body. Air enters in place of the bodily fluids that are excreted, from where poison is breathed in together with the air. The treatment of the plague lies in expelling plague-inducing poison from the body. Plague is incurable, yet Witte presented a few proposals for alleviating the effects of plague-inducing poison.

His point of departure is that if the plague-inducing poison that has entered the body were really res praeternaturalis, it should be removed from the body. Caustic plague-inducing poison is expelled from the body either through perspiration induced by diaphoretics or by increasing the excretion of urine, induced by diuretics. Physicians at that time agreed unanimously on the need to excrete 
plague-inducing poison by perspiration. Perspiration moves together with serum from the entire body to the surface of the skin. Since perspiration consists for the most part of watery serum, it also dilutes caustic salt acrimonies and sends them out.

The excretion of plague-inducing poison with the aid of perspiration-inducing measures, however, weakens the strength of the organism. Witte believes that in addition to diaphoretics, diuretics should also be used that do not weaken one's strength but rather thrust serum from the body's inner veins into the bladder and from there out of the body. Caustic salt is dissolved and diluted, and it is expelled with the aid of both diuretics and diaphoretics. In both cases, the aim is to excrete the plague-inducing poison together with the serum.

There is one more treatment method that can be used to fight plague-inducing poison: alterant medicines are also used to alleviate the effect of plague-inducing poison that has found its way into the organism. This approach could at least make the plague-inducing poison less harmful.

Witte proposes the following ways to weaken plague-inducing poison, demonstrating his extensive knowledge of chemistry.

Firstly the disengagement of the plague-inducing poison using all manner of caustic agents (Corrosiva omnimoda ablatione), that is, the use of the power of caustic salts to alleviate the caustic plague-inducing poison. Witte considers the use of acids, particularly acetic acid, to be most effective in blunting the gnawing spikes of salt. Acids may significantly weaken the strength of the caustic poison.

Witte proposes fatty and oily mixtures of medicines as the second possibility to alleviate plague-inducing poison. Since such mixtures are sticky, they would hinder the movement of the plague-inducing poison in the organism. He points out the use of wax in graphic art as an analogy. Fatty and oily medicines cannot be administered orally since plague-inducing poison does not proceed to the stomach through the mouth, instead unnoticeably penetrating the interior of the body itself. This is not noticed before it has already overrun all the defences of the internal organs. Witte believes that physicians will in the future come up with a specific alterant curative remedy and the manner for administering it that will be suitable for countering plague-inducing poison.

Knowledge of how to fend off the plague came in handy for Witte himself nine years later in combating the plague epidemic of 1657 as Riga's municipal physician, for which he was ennobled as part of the Swedish nobility. As his 
official duty and together with his older colleague, Chief Municipal Physician Reinhold Middendorff, he no doubt had to issue preventive regulations meant to be followed by city residents to impede the plague epidemic. Witte's book on this topic Kurzer Unterricht von der Pestseuche, die anno 1657 zu Riga und in Livland grassiret (Recke \& Napiersky, 1832, p. 550) would provide us with information about what anti-plague measures he prescribed and about how effective they were. Unfortunately, not a single copy of this book is known to have survived to the present. ${ }^{5}$

Witte's views on prophylactic measures to combat the plague and its treatment apparently corresponded to generally accepted perceptions, yet in some respects he was clearly ahead of his time. Nowadays we know that plague bacteria causes the plague and that fleas nesting in the fur of black rats spread that bacteria. It spreads very rapidly from human to human as droplet- and contact infection. What Witte's understanding of the causes and prevention of the plague was can only be appraised in the context of the widespread viewpoints of the mid-1 $17^{\text {th }}$ century. The Estonian folklorist Reet Hiiemäe (2003) has written a comprehensive synoptic summary of views on the plague in early modern Europe. On this background, Witte's views on the plague can be compared to current views of that time. Miasma, that is poisonous air pollution, was considered the cause of the plague from Hippocrates onward. Poisonous fog or smoke spreads the plague. When the constellation of the planets is unfavourable, harmful vapours are sucked from the surface of the ground into the air and as they become heated, they descend back down to the surface of the ground as plague-inducing poison. It was not until the $18^{\text {th }}$ century that the teaching of miasmas began to recede. Many people, for instance Girolamo Fracastoro in the $16^{\text {th }}$ century, had speculated that illness germs cause the plague just like other contagious diseases. In 1527, Paracelsus expressed the opinion that the plague is an arsenic illness (Lindroth, 1943, p. 335). Upon examining the blood of plague victims with a microscope in 1646, Witte's contemporary Athanasius Kircher also arrived at the conclusion that minute infectious worm-like micro-creatures cause the plague. Yet this did not reach the public until the book Scrutinium pestis was published in 1658. It is, however, true that Kircher thought that blood cells were the agents of the plague (Enzyklopädie Medizingeschichte, 2005, p. 750).

In the opinion of Alard Moritz Eggerdes, a German active in the field in the first half of the $18^{\text {th }}$ century, the plague does not arise from bad seasons of the year

I owe a great deal of thanks to the Latvian book historian Aija Taimina for her assistance in looking for this publication. 
or the unfavourable positioning of the stars, from poisoned air or malignant vapours rising from the earth. Instead, it originates solely from the poison that is conveyed to us from infected places (Hiiemäe, 2003). As a general rule, his theory was still based on the teaching of miasma. In practical terms, however, the only correct course of action was taken: the plague quarantines that were established clearly expressed the recognition of contagiosity. Had miasmas been the cause of the disease, quarantines would have been useless.

In Witte's opinion, the air is not corrupted in its own substance (Aer...corrumpitur, non quidem in propria sua substantia), rather its corruption is caused by particles of arsenic as the most poisonous plague germs (seminaria pestis). Thus Witte based his theory on the opinion of Paracelsus. Here it is recognised that the disease is caused by specific imperceptible pathogens. This, in turn, makes it possible to render specific treatment to combat specific pathogens. Witte also referred to such possibilities. On many occasions, Witte also referred to the particles of plague-inducing poison as poison atoms (atomi venenata, exhalationes venenati aeris arsenicales), presumably inspired by Sennert's theory of atomism.

The unfavourable positioning of the stars and God's punishment of mankind for leading a life of sin were often seen as the overriding cause of the plague. Both of these explanations had also found a central place in the teachings of Paracelsus. Witte distanced himself from these two explanations, leaving the discussion of the wrath of God to the sphere of activity of theologians while he himself strove to investigate the causes of the plague deriving from nature. ${ }^{6}$

Witte also shared the general opinion that the plague could be kept at a distance by building open fires. No doubt, the smoke from open fires disinfected the immediate vicinity and also warded off the movement of infected rats. Ringing church bells and firing cannons to induce the motion of air was widely recommended at that time as a prophylactic measure against the plague. Witte considered its effectiveness marginal compared to building open fires.

${ }_{6} \quad$ Astrologi pro causis superioribus nobis obtrudunt nescio quos peculiares stellarum influxus, adspectu /.../ et conjunctiones quorumdam planetarum verum illi, praeter scitam inscitiam nos nibil docent, neque enim explicant, qua ratione, aut per quid influant. Nudae autem illorum adsertioni fidem habere non possumus. Philosophia enim liberratis regnum est (vel certe debebat esse), in qua persuadere rationibus, non auctoritatibus cogere licet. Nonnulli ut quoddam ignorantiae suae velandae siparium obtendant, quum in causis pestis extricandis ipsi intricati essent, ab astris ad astrorum auctorem Deum confugiunt, a quo pestem in poenam peccatorum, absque ulla aeris corruptione, immediate immitti dicunt. Verum, ut pestem immediate a Deo absque ullis causis secundis immuti posse non negamus, ita illam pestis considerationem Theologis relinquimus: Nos vero, pestis a naturalibus causis excitate naturam scrutando, id agimus quod medicorum est, apud quos immotae veritatis regula esse debet: Causa prima non excludit secundam. Sed has et alias opiniones suis auctoribus defendendas relinquimus, non tam de alienis convellendis, quam de propriis firmandis soliciti. (Witte, 1648, Thesis 11) 
As a general rule, excretory agents, including bloodletting, were used against the plague in the hope that this would reduce the relative proportion of corrupted bodily fluids. Witte did consider the use of excretory preparations feasible, yet the recommendation of specific alterant medicines in cases where the plague had already penetrated the organism was novel. The method of alterant treatment attempts to inhibit the strength of the poisonous salt acrimonies by blunting their spikes with strong antidotes. This is, in essence, the principle propagated by Paracelsus, where the similar cures the similar.

The consumption of vinegar, sour milk and sourish plants was considered extremely important as prophylactic measures against the plague because acid supposedly prevented the spoiling of bodily fluids and the plague that arose from it. Witte considered the use of acetic acid very much advisable to combat the plague. Nevertheless, the addition of acetic acid to the water in Heron's steam engine that was to be transferred to the air apparently had no effect against the plague.

Where could Witte have gained inspiration for writing his doctoral dissertation on the theme of the plague in particular, cannot be answered. The plague was common enough a phenomenon in those days and was also discussed regularly by scholars.

Still, it can be surmised from the dissertation that he had been told about the plague epidemic that decimated Holland, including Leiden, in the mid-1630s. It is possible that Witte was inspired to approach this theme by a work on that plague epidemic published two years previously by Isbrand van Diemerbroeck (1609-1674), who was shortly to become a professor at the University of Utrecht in 1649 (Diemerbroek, 1646). The plague that broke out in the mid-1630s in Nimwegen, where Diemerbroek served as a physician, formed the basis for this work. 


\section{The application of the theory of blood circulation in Witte's disputations}

Nicolaus Witte was fortunate to study at universities in the Netherlands at a time when the environment at those universities was exceedingly favourable for the acceptance of the theory of blood circulation. Professors at those universitiesJohannes Walaeus at Leiden and Henricus Regius at Utrecht—actively justified Harvey's theory of blood circulation. It was the publishers at Leiden in particular who at that time published publications one after another substantiating the theory of blood circulation. The question of who Witte considered to be the first to discover blood circulation is of little importance, yet nevertheless unavoidable. Was it Harvey, some Italian, or Hippocrates? Namely, just before Witte arrived at Leiden, Thomas Bartholinus had sent word from Italy to his teacher Walaeus in autumn 1642 about a rumour that the person who had actually discovered blood circulation was Paolo Sarpi, a cleric from Venice, from whom Harvey got his original idea for his theory of blood circulation. Walaeus believed the rumour and published notice discrediting and compromising Harvey's authorship in 1645 as an expanded version of the letter he sent to Bartholinus in 1640 (de Wale, 1942, pp. 14, 62; Schouten, 1974, p. 265). Professor van der Linden from Franeker, however, altogether ascribed the idea of blood circulation to Hippocrates (see above). Not one of Witte's three disputations specifically considers the activity of the heart or the movement of the blood, yet Witte uses the theory of blood circulation to explain the internal causes of dropsy, arthritis and the plague. Namely, it is standard practice to include a section explaining the internal causes of illnesses in the structure of medical disputations and it is precisely here that the disputation's author faces a dilemma in choosing which concept of physiology to favour. Observe how Witte has used blood circulation to substantiate his positions. When speaking of dropsy, Witte considers one reason as to why sharp salt acrimonies do not manage to gnaw through the walls of blood veins to be the incessant circulation of blood, which does not allow that to happen. ${ }^{7}$ Elsewhere Witte points out that the cause of dropsy is often constrictions in the path that serum has to pass through. Yet the constant movement of blood that returns again into circulation with each heartbeat prevents the blockage of the blood and dropsy arising from it. ${ }^{8}$

Per diaeresin ab erosione factam id fieri, nequit suaderi, cum serum salis erodentem acrimoniam obtundat, atque sangvini permistum in perpetuo sit fluxu, ita ut vasa non possit exedere, et excedere (Witte, 1645, Thesis 11).

$8 \quad$ Itaque frequens sane hydropis causa est angustia viarum, quas serum transire debet. A subsidentia, vel a coalescentia, vel constrictione illam oriri posse non permittit perpetuus ille sanguinis motus, per pulsum cordis in circulum rediens (Witte, 1645, Thesis 25). 
Witte repeats the same idea in the $28^{\text {th }}$ thesis of the same disputation: blockages can occur in liver veins, especially in their capillary branches, but this kind of blockage does not occur in the stems and portals of blood veins where the blood passages are broad and unobstructed, nor does circulation make it possible to displace it when the blood energetically and uninterruptedly moves on from the heart. $^{9}$

Witte expressed the idea of blood circulation altogether more thoroughly in the $15^{\text {th }}$ thesis of his disputation of 1647 on arthritis. In saying that the passages for the movement of serum into the joints are the blood veins, primarily the arteries, he explained that the blood is forced through the arteries together with the serum into the organs of the body and that it returns from the periphery of the parts of the body through the veins to the heart. He mentions the valves of blood veins that had been recently discovered due to which the motion of the blood is open only in one direction, that is, in the direction of the heart, as an important circumstance that proves the existence of blood circulation. Yet the path in the direction of the periphery of the body is shut in the veins so that the blood could not return there. ${ }^{10}$ Witte had in mind the discovery of blood vein valves in 1603 by Girolamo Fabrizio (Fabricus ab Aquapedente), who was Harvey's teacher at Padua, which served for Harvey as a circumstance that corroborated blood circulation.

In his doctoral dissertation of 1648 on the plague, in which he wrote of the spread of poisons by way of the blood throughout the organism, from where it arrives back at the heart and that the rest of the poisons also force their way into the blood through fermentation, Witte did not neglect to mention that blood flows through the heart, which is the blood's workshop, and returns. That is why the blood forces the plague-inducing poison that has made its way into the rest of the parts of the entire body into the heart. ${ }^{11}$

9 In ipso hepate ex eadem causa in venis obstructio oritur, praesertim in ramis earumdem capillaribus; nam in truncis et portis vasorum talem obstructionem fieri non ita crediderim, cum viae sint admodum latae et patentes, nec impetus sanguinis perpetuo a corde in circulum propulsi illam admittat (Witte, 1645, Thesis 28).

10 Ego non alium terminum a quo agnosco, quam vasa totius corporis, ut ex praecedentibus patet. Quae etiam sunt viae, per quas serum ad articulos movetur. Potissimum tamen per arterias fit ille in fluxus: per illas enim sanguis cum sero ad habitum corporis pellitur: per venas autem ab externis partibus ad cor redit, quod indicant valvulae illae venarum nuper inventae, quae versus cor sunt apertae, versus habitum corporis clausae, ne sanguis ad illum remeare possit (Witte, 1647, Thesis 15 ).

11 Idem fit in aliis venenis peros ingestis, corrosivis scilicet. Reliqua quoque venena malitiae suae characterem sanguini per fermentationem imprimunt: sanguis vero, quum per cor, sanguinis officinam, eat redeatque, ideo quoque cordi illam noxam imprimit: neque cordi soli ex singulari quadam et occulta antipatheia, sed etiam reliquis totius corporis, ad quae defertur, membris, quae sanguinis infecti noxam aeque, ut cor, sentire et luere coguntur. (Witte, 1648, Thesis 21). 
At the same time, Galen's principle of the division of blood was also still alive and well at Leiden. The Galenist basic concept of Johann Coster's doctoral dissertation on smallpox and measles defended in 1645, a couple of months before Witte defended his disputation on dropsy, is an indication of this. The $14^{\text {th }}$ thesis of Coster's dissertation states that infected blood moves from the larger veins into ever narrower veins and through them into the body and to the surface of the skin. Coster was a fellow student of Witte's and later became the archiater (chief physician) of the Russian tsar and of the King of Sweden. Coster was also the chief physician of the Knighthood of the Province of Estland. ${ }^{12}$

The theory of blood circulation created a dilemma for scholars: the old physiology that had stood the test of time no longer fit in with the new theory. The reinterpretation of physiology began gradually through scientific experiments that continued at an autocatalytic pace throughout the latter half of the $17^{\text {th }}$ century. The first reappraisals, however, took place during Witte's years of study already. One of the problems was to discover how the blood that arrived from the arteries into the periphery of the body got into the veins.

Harvey thought that the transfer of blood from the arteries to the veins in the periphery of the body takes place through porosities. Johannes Walaeus arrived at the same conclusion in experiments conducted in 1640 (Rotschuh, 1957, p. 606). Witte considered it natural that light particles of serum water easily pass through the pores of blood veins and even more easily through the anastomoses of arteries and, needless to say, through the walls of veins where acrimonies have burrowed through them. ${ }^{13}$

Witte uses the concept of capillaries as a technical term in his disputations, although it was only in the latter half of the $17^{\text {th }}$ century that the term acquired its current meaning. Did Witte use the concept of capillaries in its correct meaning when it was not until a couple of decades later that Malpighi in 1661 and Leeuwenhoek in 1688 found proof of their existence by observation through the microscope? What Witte presented in his disputation of 1645 , however,

12 Quo natura sanguinem hunc impurum multorumque excrementorum permistione inquinatum exturbet, eius effervescentiam et ebullitionem instituit, qua illud, quod inquinabat, a magnis venis ad parvas, ab his ad minores, a minoribus ad minimas, donec ad corporis habitum et cutim ipsam perventum fuerit, expellitur, non secus ac mastum impuro vasi infusum, et ab eo prava qualitate imbutum per ebullitionem seipsum et dolium purificat. (Coster, 1645, Thesis 14).

13 Per diapedesin id fieri posse non adeo obstinatus negarem, cum tenues, laeves et flexiles aquae particulae facile poros vasorum transire possint, nisi longe facilior esset via per anastomosin, et maxime arteriarum, ut pote quia majore seri copia abundant, et per pulsum citius possunt aperiri. Et ratio certe suadet, in fluxu tam seri, quam sanguinis, aperiri oscilla vasorum: nam si per exesa vasa sanguis exiret, non posset tam repente sisti. (Witte, 1645, Thesis 12). 
speaks for itself: in speaking of one of the functions of serum as diluting the blood and reducing its viscidity and density, he had in mind that blood as a means of conveyance could more easily reach parts of the body requiring nourishment through the narrow passages of the capillary veins. ${ }^{14}$ Furthermore: "Blood proceeds through smaller arteries and venules and their capillary branches." 15 Witte uses the concept of capillaries in its correct meaning, apparently according to the example of both Harvey and of Witte's teacher Johannes Walaeus (see de Wale, 1942, p. 59; Schouten, 1974, p. 271). Hermann Conring also used the concept of capillaries in its correct meaning in his work on blood circulation published in 1643 at Leiden (Rosner, 1969, p. 298).

While in the tradition of Galen's teachings the liver was considered the selfevident organ for producing and processing blood where blood is continuously regenerated out of chyle, then according to the theory of blood circulation, the heart is the organ that produces and processes blood. Evidence disproving the role of the liver was still scant at the time when Witte was writing his dissertations. The writings on this topic by Jean Pequet, Thomas Bartholinus and Olaus Rudbeckius went into general circulation among men of science only after Witte had completed his studies in the Netherlands and returned to his home town of Riga to begin his medical career there. Witte's position is that the primary workshop for producing blood is the heart instead of the liver and he clearly expresses this in his disputation of $1645 .{ }^{16} \mathrm{Witte}$ also expressed the idea of the heart as the workshop of the blood in Thesis 21 of his doctoral dissertation of 1648 (see above).

Witte firmly believed that the liver is not the workshop that produces blood. He refuted Galen's proponents with a rhetorical question presented in the $16^{\text {th }}$ thesis of his disputation of 1645 , asking whether liver failure can be the cause of dropsy. Witte says that in any case, the thesis put forth by Galen's proponents of the immoderately cold liver is not valid. Galen's proponents present four contradictory points to substantiate their claim:

1. The liver is the workshop for producing blood.

2. The cause of dropsy is the excessive coldness of that same organ.

14 Ut chylum per venas lacteas deferat, et sanguinis a corde impulsi lentorem et crassitiem diluat, ut eo facilius, hoc auriga usus, per angustus vasorum capillarum meatus ad partes alendas pervenire possit (Witte, 1645, Thesis 19).

15 Serum ideo sanguini per minima permiscetur, tum, ut sanguinis diadosis per minimas arterias et venulas, earumque ramos capillares promoveatur (Witte, 1645, Thesis 35).

16 Secundam seri a sanguine segregati causam diximus esse remissum calorem cordis. Hoc enim primariam sanguinis officinam esse cum viris cordatis adserimus. (Witte, 1645, Thesis 38) 
3. The illusory completion of blood derives from that cold akrasia, and

4. The transformation of chyle into serum instead of blood.

Witte considers the foundation for the position that the liver is the workshop for producing blood to be very weak and is categorically opposed to this viewpoint. ${ }^{17}$

In order to understand the background of Witte's bold display in its time and space, recall that just a few months earlier, Georg Siegfried Freudenhammer had represented precisely Galen's position that dropsy derives from the cold immoderateness of the liver in the doctoral dissertation on dropsy that he defended at the very same university.

A good example of how Witte had found himself in the middle of the trial and error of the search for scientific truth is the problem of the spleen, which appears insignificant at first glance. It was important for Witte, since blood veins are intertwined in numerous places in the spleen and blockages that frequently occur in those areas can cause dropsy. What is important, however, is his observation that the blood in the blood veins of the spleen contains considerably more serum than blood in the liver, to which chyle is transported. We know, however, that according to Galen, blood was supposed to move from the liver to the spleen, where new blood produced from chyle is cleansed. Walaeus, on the other hand, ascertained by ligating the portal vein that no blood flows from the liver to the spleen. On the contrary, blood flows from the spleen to the liver. Thus it is not possible that black bile flows from the liver to the spleen as Galen proposed and thus the spleen is not for cleansing blood coming from the liver. Secondly, all the blood in the spleen is of arterial origin. It comes directly from the heart through the aorta and the spleen arteries. This evidence places the blood of the spleen within the framework of the theory of blood circulation (Trevisani, 2011 , p. 209). Witte's opinion that the blood of the spleen contains more serum than the blood of the liver can also be viewed in this light. The problem of the passage connecting the spleen to the stomach, however, is more important for

17 Vitio autem causae efficientis, nimirum ab intemperie epatis frigida ob apotychian $t$ haimathoseos, serum generari, nulla, quamvis delenifica, Suada a me impetrabit. Quatuor enim maxime controversa hac unica adcertione ponuntur, quae censoria virgula digna sunt.

1. Epar esse officinam Haimatopoieseos.

2. Hydropis causam esse frigidam eiusdem intemperiem

3. Ab eius frigida akrasia oriri frustratam sanguinis confectionem, et

4. Chyli pro sanguine in serum conversionem.

Quod si probatum fuerit hepar non esse officinam haimatoseos, jam res erit confecta: hoc enim subtracto tibicine totum superstructae opinionis aedificium corruet. Sed quoniam hoc nimis longum heic foret, et ego spaciis inclusus iniquis praefixos disputationis limites excedere neqeo, ideo in ipso conflictu pro virili negantem sententiam tuebor. (Witte, 1645, Thesis 16) 
Witte. According to Galen, venous blood flows through a short vein from the spleen to the stomach. Vesalius did not find any connecting passage whatsoever and thus cast doubt on this claim (Rothschuh, 1968, p. 53). Witte, however, argued against the viewpoint that had recently been disclosed according to which chyle moves from the stomach to the spleen, causing obstruction of blood. On the strength of an experiment demonstrated by his supervisor Walaeus, Witte considered this claim untenable since there is no vein through which watery chyle could move from the stomach to the spleen. ${ }^{18}$

The original source that Witte most likely relied on is the 1640 letter from Walaeus to Thomas Bartholinus, in which he says that sometimes he has been shown chyle veins that lead to the spleen but upon closer examination in the presence of the presenter of this claim, he has ascertained that what appeared to be veins are nerves instead. Chyle veins transport chyle into the portal vein in the branch of mesenterium veins and mixes with blood in the liver itself. ${ }^{19}$ Thus we can interpret Witte's indirectly stated text as indicating that blood from the spleen does not come from the liver or the stomach and thus it would have to be arterial blood coming from the heart, thus placing this claim in the context of the theory of blood circulation. Neither Walaeus nor Witte would have necessarily yet known that it is not the liver that processes chyle into blood. This became clear a few years later in 1647 after Jean Pecquet discovered the ductus thoraticus (thoracic duct). More properly speaking, this became known after the publication of the results of this discovery in 1651 (Trevisani, 2011, p. 210).

Considering what has been presented above, it is important that Witte did not discuss circulation of blood expressly in his theses. To treat the theory as a matter of fact and a self-evident information tells about a thorough adoption of the theory of blood circulation.

Nicolaus Witte can justifiably be considered an early proponent of the theory of blood circulation and he merits a place in the pages of medical history. Secondly, Witte's disputations show that the theory of the circulation of blood

18 Lienis obstructiones etiam satis sunt frequentes, nam innumerabiles arteriarum plexus inter se complicati ad eum feruntur, quae longe serosiorem in se contingent sanguinem, quam venae hepatis, ut pote quarum sanguis novo chyli advenientis balsamo instauratur. Illi plexus cum sint varie inter se contortuplicati, facile in illis maeandris potest materia aliqua crassa remanere, quae obstructionem pariat. Quaecumque autem longo verborum adparatu de vade brevi a ventriculo ad lienem tendente, eiusque obstructione a nonnullis dicuntur, illa nom opus est heic refutare, cum Cl. D. praeses jam et rationibus et autopsie demonstrarit, non dari tale vas breve, per quod lien a ventriculo chylum aqueum ad se trahat, ut loquuntur (Witte, 1645, Thesis 29).

19 Zuweilen sind uns auch Milchvenen gezeigt worden, die zur Milz verlaufen sollten, aber bei sofortiger und genauer Nachsuche in Gegenwart derer, die das behauptet hatten, stellten wir fest, daß es Nerven waren. Durch diese Milchvenen wird der Chylus geleitet und in dem Mesenterialast, in der Pfortader und in der Leber selbst dem Blut beigemischt (see de Wale, 1942, p. 22). 
was integrated in the academic learning in that period. The example of Witte should provide inspiration for closely examining all the medical disputations defended in the 1640s from the standpoint of the reception of the theory of blood circulation.

Of the three most influential doctors from Eastern Europe who studied at the University of Leiden at the same time, around 1643-1645, Witte von Lilienau and Johannes Michel, personal physician of the Duke of Courland, were supporters of Harvey's theory of blood circulation. Johann Coster von Rosenburg, however, as the archiater (chief physician) of the crowned heads of Russia and Sweden, was in physiology a supporter of Galen. The data presented above permits Nicolaus Witte to be considered the first known doctor working in the Baltic region who supported the theory of blood circulation.

\section{Can Nicolaus Witte be considered an early Cartesian?}

The circle of persons in the dedication of the disputation that Witte defended in 1645 is extremely interesting from the aspect of researching the reception of ideas. Witte dedicated this disputation to ten individuals. Descartes and his friends and supporters accounted for altogether six of them. Naturally, the first person listed was the rector of the university, whom the success of the disputation largely depended on. The rector was an elderly 77-year-old theology professor named Johannes Polyander ab Kerkhoven with moderate views, who died six months later. Yet, most importantly, in second place among the people the work was dedicated to was Rene Descartes as the father of revived philosophy (renatae philosophiae parens). The following names were faithful friends of Descartes: physician Johann van Beverwijck (1594-1647) from Dordrecht, physician Cornelis van Hoghelande (1590-1662) from Leiden, professors of medicine at Leiden Adolf Vorstius (1597-1663) and Johannes Walaeus (1604-1649), and Henricus Regius (1598-1679) from Utrecht. They were followed by the lectors Nicolaus Hasius and Albert Kyper (about 1614-1655) from Königsberg. The list of persons to whom the disputation is dedicated to ends with Gerardus Joannes Vossius (1577-1649), history professor at the Amsterdam Atheneum, who shared a common interest in philology with Witte.

All three professors of medicine to whom the work was dedicated communicated to a greater or lesser extent with Descartes. As a philosopher, Descartes did not 
have a medical education and thus had to educate himself in physiology by independent study and, to this end, he asked the most prominent experts in the field for advice. During his Leiden period, he relied first and foremost on Adolf Vorstius and Johannes Walaeus. Adolf Vorstius appeared to be one of Descartes's friends (Verbeek, 1992, p. 120). In any case, in summer 1643, when Witte had been in Leiden for half a year, Vorstius and Descartes corresponded with each other (Lindeboom, 1978, pp. 33, 43; Trevisani, 2011, pp. 200, 214). By February 1644, Walaeus read the first two parts of the manuscript of Descartes's Principia philosophiae that was published that same year and introduced it to his students as well (Trevisani, 2011, p. 209). Needless to say, Henricus Regius, professor at Utrecht, had the closest contacts with Descartes which lasted until 1646, when the cautious Descartes, fearing accusations of atheism, distanced himself from his ally Regius after the latter published of his radical Fundamenta physices.

The fact that Witte dedicated his public disputation to Descartes as "renatae philosophiae parens", is precise in the context of the developmental perspective of philosophy since it is precisely the philosophy of Descartes that brought about a change in paradigm by succeeding in breaking down the monopolistic status of the philosophy of Aristotle by the end of the $17^{\text {th }}$ century, thus liberating philosophy from the patronage of theology and opening up the way for new directions in philosophy. Yet at that time, this kind of manifestation in a student's public written work was a truly unusual and daring enterprise even in relatively tolerant Holland. Since he was a student, his opponents could have hindered his further academic studies. Namely, theologians in Utrecht uncompromisingly began to attack Descartes' ideas in 1643, that is, the year that Witte went to Holland. In this light, it must be considered very important that Witte also visited the University of Utrecht in 1644, where he became closely acquainted with Professor Henricus Regius as a propagator of the teachings of Descartes and the theory of blood circulation. Apparently, Witte found the example for the form of his dedication to Descartes from Regius, who "credited Descartes as the restorer of philosophy" (Vermij, 2002, p. 165). Yet the Cartesians at Leiden had learned from Utrecht's experiences and were cautious. The controversy concerning the philosophy of Descartes was just gathering steam and the professors of medicine at Leiden did not intervene.

At Leiden, the lecturer in philosophy Adriaan Heereboord comparatively examined the teachings of both Aristotle and Descartes and related tolerantly to the opinions of students supportive of the positions of Descartes in disputations. 
Since Heereboord was far more cautious compared to Professor Regius at Utrecht, controversies had not yet reached their climax in Leiden by 1645. By 1645, however, all the works of Descartes were available in Latin at the grassroot level to everyone studying at Dutch universities: the Latin translation of Discourse on Method and Principia philosophiae had been published in Amsterdam the previous year and the second edition of Meditationes had been published in Amsterdam three years before that. A number of works of supporters and opponents of Descartes had also been published. Thus Nicolaus Witte also had ideal opportunities for keeping abreast of the ideas of Descartes. The extent to which he was actually interested in the views of Descartes, whether it be method, proof of the existence of God, or natural philosophy, remains unclear. At any rate, ideas adopted from the works of Descartes are not found in any of his disputations. Witte could indirectly have gained support from Descartes for his contempt for authorities, yet the works of Bacon or Gassendi could have served as examples for him all the same. The subject matter regarding proof of the existence of God was of interest primarily to students of theology. A comprehensive Cartesian consideration of the human being shaping the views of physicians was to a great extent latent for an entire generation. The work De homine that had already been completed in 1632 was not published until 1662 . Aristotle's philosophy and physics still remained in place in curricula as a firm paradigm while Witte was in Holland. Even though all of the more important works of Descartes were published at that time, and some even as repeat editions, a struggle between Cartesians and their opponents lasting several generations was required for the paradigmatic breakthrough of his ideas (see Trevisani, 2011, passim).

Witte was fortunate to become personally acquainted with first-generation Cartesians in particular who tried to adapt the teachings of Descartes to the views they had hitherto held. To the extent that theologians saw a real threat to theology and philosophers felt that Aristotle's entire teaching of philosophy was endangered by the method of doubt of Descartes and his proof of the existence of God, they did all they could to ban the teachings of Descartes. Needless to say, this only increased the interest of scholars in the ideas of Descartes and swelled the ranks of the Cartesians. While Witte was in Holland, several lecturers had only just begun examining the teachings of Descartes but within the framework of Aristotle's teaching. Students could indeed debate on the principle of doubt or proof of the existence of God in their practice works at Leiden and Utrecht, but Cartesian ideas did not appear in inaugural dissertations until the time of succeeding generations. Some fellow students who studied at the same time 
as Witte developed into influential Cartesians, for instance Johannes De Raei (1622-1702), who continued his studies at Leiden at the same time as Witte in 1643 after studying at Utrecht and later became professor at Leiden and Amsterdam, or Johannes Clauberg (1622-1665), who later became professor at the University of Duisburg.

Returning to Witte's dedications, let us be guided by the fact that it is precisely the blood circulation theory presented in the work by Descartes entitled Discourse on Method that is an outstanding example of the application of the proof of his method and movement contributed to the triumphal progress of the spread of the blood circulation theory. Thus supporters of the blood circulation theory had reason to be grateful to Descartes even if they did not necessarily favour his philosophy. Proceeding from this, not one of the persons that Witte dedicated his work to is known to have been an opponent of the blood circulation theory. Most of them, including Cartesians, were supporters of the blood circulation theory.

The circle of people chosen by Witte in his series of dedications probably did not spring from his interest in philosophy but rather those same individuals to whom the work was dedicated were at the same time supporters of the theory of blood circulation. The fact that we do not find Adriaan Heereboord, a direct supporter of the philosophy of Descartes at the Faculty of Philosophy of the University of Leiden, the mathematician and orientalist Jakob Golius, a friend of Descartes, or the professors of practical mathematics, the father and son Franz van Schooten (senior and junior) among the persons Witte dedicated his work to provides further confirmation that Witte himself was not interested in philosophy. This is an indication that Witte was not closely acquainted with them. All the friends of Descartes and the philosopher himself to whom Witte dedicated his work, including Walaeus, Beverwijck, Hoghelande and Regius, also made a significant contribution to spreading the theory of blood circulation. Vorstius was in the same boat as Walaeus, having conducted blood circulation experiments together with the latter (Schouten, 1972, p. 11; Trevisani, 2011, p. 216). One of the people to whom the work was dedicated, the youngish lecturer Albert Kyper was an Aristotelian and as such, publicly opposed to the ideas of Descartes, yet he tolerated the teachings of blood circulation (Ruestow, 1973, p. 39ff). The theory of blood circulation did not contradict Aristotle's teaching of causality, all the more so that Harvey himself was a confirmed Aristotelian (see Fuchs, 1992, p. 44). Presuming that the circle of individuals to whom Witte dedicated his work consisted without exception of supporters of the theory of blood 
circulation, we can, as it were, make a sociometric observation: the professors of medicine at Leiden who we do not see among the individuals to whom Witte dedicated his work were professors of medicine of the older generation: Otto van Heurne (1577-1652), Adriaan Falcoburgus (1581-1650) and Evald Schrevelius (1575-1647). The first two of these professors had perforated the septum of the heart ventricle in previous anatomy demonstrations in order to demonstrate the existence of pores in the septum and thus the accuracy of Galen's teachings through falsification (Lieburg, 1982, p. 43; Schouten, 1972, p. 15). Needless to say, Utrecht professor of medicine Willem van der Straaten (1593-1681), who as an anti-Cartesian and opponent of the theory of blood circulation attacked his colleague Henricus Regius (Verbeek, 1992, p. 17), was not part of the circle of persons to whom Witte dedicated his work. If we consider the numerical relation of forces between conservative and pioneering professors at Leiden, those siding with the theory of blood circulation were clearly in the minority. Johannes Walaeus was only a professor extraordinarius until 1648. Adolf Vorstius, who had participated in experiments proving blood circulation together with Sylvius and Walaeus, was himself more dedicated to botany.

It appears that by the time Witte came to study at Leiden, the theory of blood circulation had been convincingly proven as far as its supporters were concerned. Its opponents, however, did not see it as any particular threat to the teachings of Galen, at least until Jean Pecquet's discovery of the ductus thoraticus (thoracic duct), which conclusively proved that the liver is not a blood-producing organ. It is at Leiden that numerous works confirming the theory of blood circulation appeared during the time that Witte studied there (for instance by Hermann Conring in 1643). Divergences of opinion, however, did emerge in the camp of the supporters of the theory of blood circulation between the vital model of blood circulation based on Harvey and the mechanical model based on Descartes. Thomas Bartholinus, for instance, favoured Harvey's model, while the vast majority of the supporters of the theory of blood circulation, including Henricus Regius and Johannes Walaeus, favoured the mechanical model (Fuchs, 1992, passim).

Did Witte communicate personally with Descartes? This is not altogether impossible, although Descartes' preference of privacy should be remembered. While Descartes maintained an extensive correspondence, he interacted with only a very narrow circle of select friends while living incognito here and there in the vicinity of Leiden. It appears that Johannes Walaeus was part of that circle of friends. Witte might have visited Descartes in the company of his teacher Walaeus or together with Vorstius. The circumstance is that there is not a single 
letter from Witte among the printed correspondence of Descartes but there is a letter or several letters from Descartes among them (Witte, 1688, p. 5).

Even though direct influences of the method of doubt or the natural philosophy of Descartes are not apparent in any one of Witte's disputations, it appears that Witte tried to copy the style of Descartes. Like Descartes, Witte also does not quote any author by name to support his positions. Descartes intentionally used originality and contradiction of previous thinking according to schools of thought (Friedenthal, 2014, p. 14). The philosophy of Descartes provided impetus to the notion that instead of studying ancient texts, nature itself should be studied. Francis Bacon in his Novum Organum Scientiarum (1620) had also levelled criticism at the preceding scientific heritage, particularly that of antiquity, accentuating different ways of erring (so-called apparitions) that prevent arriving at the truth. Yet Pierre Gassendi's Exercitationes Paradoxicae of 1624 also provided impetus for a sceptical attitude towards Aristotle's philosophy. Witte had several examples from among seventeenth-century thinkers for contradicting the hitherto existing scientific heritage. At that time in the $1640 \mathrm{~s}$, a sceptical attitude towards generally accepted authorities was nevertheless not yet usual in the disputations of students. The masterpieces of Descartes and Bacon were available to Witte because a Latin translation of Descartes' Discourse on Method, the first edition of which was published in French in 1637 in Leiden, was published in Amsterdam in 1644. The second edition of Bacon's Novum Organum Scientiarum was published in Leiden in 1645, thus right within the time and space of Witte's studies. Furthermore, Witte was well acquainted with Isaacus Gruterus, the keeper of the manuscripts of Bacon's works and later publisher of those works. Gruterus published a congratulatory poem on the occasion of Witte's defence of his doctoral dissertation.

Before Witte left Leiden for Franeker in the scandal that erupted over the method of doubt, professor of philosophy Heereboord presented an argument in defence of the method, pointing out that Descartes' method of doubt is the same as Bacon's doctrine of idols (Verbeek, 1992, p. 40). It appears that Witte preferred the method of rationalist deduction based on Descartes as a scientific method over the induction method based on Bacon.

Witte's reliance on rationalist principle emerges with complete clarity in the $8^{\text {th }}$ thesis of the doctoral dissertation that he defended in $1648 .^{20}$ Here he says that

\footnotetext{
$20 \quad$ Nos, ne videamur sententiam nostram in rerum naturam intulisse, omnes causas capite arcessemus, et ratiocinando progrediemur, donec ad ultimam aliquam perveniamus, in qua sedem et pedem figere possimus: ingenue professi, nos non auctoritatis aut sectae alicujus, sed rationis dictamen unice sequuturos. (Witte, 1648, Thesis 8).
} 
we do not see that our opinion has penetrated the nature of things. We work out all causes in our own head and proceed to draw reasonable conclusions until we arrive at some extreme limit where we could stop, openly acknowledging that we do not proceed according to the dictates of any authorities or sects but rather only according to those of reason.

Proceeding from this, the principle that runs through Witte's disputations is abandoning blind faith in the claims of authorities. His attitude towards using the works of the authorities of antiquity in particular, but also those of authorities from more recent times as a source of truth, is altogether disdainful. Witte says in the introduction to his disputation of 1645 that he distances himself from old opinions and presents new opinions without being guided by any sect. He claims that the excessive veneration of the authors of antiquity had more likely damaged medicine more than rationally familiarising oneself with innovations. Conservatives cling to old teachings. ${ }^{21}$ Witte says in his disputation of 1647 that he draws knowledge from the pure source of nature herself, not from the muddy quagmire of one sect or another. Namely, he claims that his soul always detests sects since one spews out the Galenic Hippocraticum, another a Hermetico-Paracelsicum. He leaves both of them aside and takes hold not of authorities but of truth that is the most everlasting. Thus the authority of truth is above other authorities. ${ }^{22}$

What Witte spells out here in print is extremely puzzling at first glance because what could irritate Johannes Antonides van der Linden (1609-1665), who presided over the disputation and is considered a fanatic who considered Hippocrates the paramount, infallible authority, more? Nevertheless, no scandal is known to have arisen from this disputation that extended into print. Perhaps van der Linden's attitude towards the dissenting opinions of students was altogether more respectful and tolerant than it appears to have been several centuries later. Otherwise van der Linden would probably not have been invited later to come from Franeker to take up the position of professor of medicine at the University of Leiden.

21 rem ipsam adcrediamur, primo omnium invidiam deprecabimur, quod ab antiquis opinionibus recedentes, novas nonnunquam adferamus, nec ulli nos ectae addicamus, cum turpe sit ex omniumrerum dictatore intellectu facere mancipium alienae libidinis, /.../ praesertim cum plus reipubl. Medicae nocuerit nimius antiquitatis pro imperio loquentis cultus, quam novitatis cum ratione conjunctae studium. Ideoque si hos, qui nova sequuntur firmissimis rationis et experientiae tibicinibus suffulta, novatorum nomine traducunt: pari jure illi, qui veterum placitis, tamquam Sireniis scopulis, unice adhaerescunt, veteratores erunt adpellandi (Witte, 1645, Introduction).

22 ex illimi ipsius naturae fonte, non ex lutulentis huius vel illius sectae lacunis haustam, non impuro praeconceptarum opinionum coeno turbatam. Semper enim animus meus detestatus est illa maleferiata sectarum nomina, dum hic se Galenico Hippocraticum, alter hermetico-paracelsicum iactat. Sed ego illos suo relinquo genio. Ego meo obsecutus sum. quem non auctoritati, sed veritati mancupare volui, quae, ut est antiquissima, ita quoque eius auctoritas omni aliorum auctoritate e nobis antiquior esse debet. (Witte, 1647, Introduction) 
One further important fact fits in with this: many researchers have demonstrated van der Linden's rigorous, disdainful attitude towards Harvey. The German researcher of Hippocrates Gert Preiser (1969, pp. 305-313), on the other hand, proved that van der Linden actually had the greatest respect for Harvey and his proof of blood circulation, even though he himself was convinced that Hippocrates already knew about blood circulation. In this light, it is understandable why van der Linden agreed to preside over Witte's disputation even though their positions regarding authorities were opposite.

The foreword to Witte's doctoral dissertation of 1648 expresses his credo as a physician. He says that he has had no need to follow the beaten path. He arrives at the measurement of truth through the unity of reason and experience. The experiences of physicians cannot always be trusted in times of plague. They did indeed treat patients but to no avail. Physicians were incapable of observing patients sufficiently diligently due to their fear of infection. The senses have been delusive for experience if reason has not guided it. These principles espoused by Witte appear to be an excellent example of the application of both Descartes' method of doubt and Bacon's doctrine of idols.

One further circumstance is eminently remarkable from the standpoint of the reception of scientific ideas: in that passage, Witte compares the situation in medical science to that which took place in astronomy. He says that in order to avoid whatever cases of error, he has gathered together all experiences that reason and the endorsement of authors founded on reason have approved. $\mathrm{He}$ has learned to pick out actual and general causes from those collected experiences through which most cases of plague and their attributes can be explained. In this he espouses what astronomers have established in their work. Astronomers have gladly adopted those hypotheses by which can save many phenomena in preference to other hypotheses. ${ }^{23}$

It is not clear whether Witte means the hypothesis of Copernicus or Brahe. It is, however, true that at that time, Holland was receptive in all respects to the heliocentric hypothesis. By the time Witte began his studies, professor of mathematics Martin van den Hoven (Hortensius) (1605-1639) at the Atheneum in Amsterdam had created a favourable background for heliocentrism. Beginning in 1634, he introduced Copernicus's system of cosmology to students (Berkel, Helden \& Palm, 1998, p. 52). It can, however, be presumed that Witte could have obtained his knowledge of the state of research in cosmology in Utrecht in 1644

23 qua in re astronomorum institutum sequutus Sum, qui illas hypotheses prae aliis amplectuntur, per quas plura phaenomena salvari possint (Witte, 1648, Introduction). 
from Henricus Regius, a supporter of the cosmology hypothesis of Copernicus (Vermij, 2002), since the professor was composing Fundamenta physices, which was published two years later. In its supplemented 1654 edition, "It compares the world systems of Ptolemy, Copernicus, Tycho Brahe and Regius' own, Cartesian scheme. He concludes that his and Copernicus' models save the phenomena best. Now, writing that the Copernican system describes or saves the phenomena best is less offensive than writing that it is true." (Vermij, 2002, p. 173) While in Franeker, however, Witte could have obtained clarification regarding problems related to cosmology from professor of logic Johannes Phocylides Holwarda, who taught there and was his own age, and who at that time was one of the few supporters of the hypothesis of Copernicus that served at universities in the Low Countries (Vermij, 2002, pp. 120, 129).

While Witte was in an environment where the steadfast authority of the truths of authors from antiquity remained intact, yet proved to be outdated in the light of new philosophical ideas and scientific theories, as a young student with a searching spirit, he encountered a crisis of authority for which he could gain theoretical support from Bacon and Descartes. Several fellow students who were immune to new ideas and returned to where they had come from with their doctorate diplomas, received for defending the teachings of Galen, apparently provided Witte with the irritating impetus for him to venture in his youthful daring to express this crisis of authority in all of his public disputations.

\section{Witte and the teachings of Paracelsus}

While faith in Galen's teachings of physiology was undermined and metallic medicines became fashionable in therapy during the period of Witte's studies at university, the teaching of four bodily fluids reigned unchallenged in pathology. Galen's humoral-pathological teaching of illnesses was adapted to the needs of the early modern period in Jean Fernel's (1497-1558) handbook based on the teachings of Aristotle and Galen (Rothschuh, 1978, p. 202). This handbook did not yet disappear from use as a textbook in the $17^{\text {th }}$ century, not even at the University of Leiden, and even Johannes Walaeus used it as the basis for his lectures (Schouten, 1972, pp. 21, 153, 159). In order to comprehend Witte's viewpoints on this theme, let us consider the differences between Galen's theory of four bodily fluids and Paracelsus's principle of three elements. According to 
Galen, illness was a deviation from the normal state of the four bodily fluids. This imbalance was caused by the excessive increase of a particular bodily fluid at the expense of another or by a deficiency of one or another bodily fluid. The basis of treatment was the diversion of the mixture of those bodily fluids that cause illness out of the body (bloodletting, agents that induce vomiting and those that help divert substances out of the body, and diuretics). Medicines were classified according to their qualities as cold, hot, dry and moist. Treatment according to the principle of opposite effect (contraria contrariis) was supposed to restore the former balance in the organism. The discharge of excess bodily fluid frees the organs of obstructions caused by the troublesome accumulation of bodily fluids.

There was no place in Galen's teaching of treatment for the treatment of specific individual illnesses.

Paracelsus (1493-1541) presented an entirely new paradigmatic viewpoint concerning diseases and their treatment. He abandoned the teaching of four bodily fluids, instead of which the basic elements of organisms are three chemical principles: combustible sulphur, evanescent mercury and salt as residue. The positions of celestial bodies affect the origin and course of illnesses.

The causes of illnesses are not deviations in the balance of bodily fluids but rather the element in the human body that corresponds to the relevant celestial body. Illness is a disorder in the balance between these principles. So-called tartaric illnesses occur when residue from undigested food and drink in the stomach are not excreted as excrement but rather find their way into the parts of the body. This residue reacts with the chemical elements, that is to say salts, in those parts of the body, forming deposits resembling tartar-in other words, tartarus. In this case, it must be possible to treat illnesses using chemical substances corresponding to the planets. It is chemically possible to produce medicines in which the main component is sulphur, mercury or salt. The organism can be supported by medicine that uniquely affects a specific illness. The idea of specific illness germs is innovative compared to Galen's conception. Paracelsus provided the impetus for the use of metallic salts, especially poisonous mercury and antimonium salts. These were adopted more and more by Galenist doctors as well, as laxatives and for inducing vomiting. The teaching of Paracelsus provided the original idea for the further development of the iatrochemical concept of medicine. When the relative proportion of chemical medicines grew ever larger in pharmacopoeias in the $16^{\text {th }}$ and $17^{\text {th }}$ centuries, the pathological part of Paracelsus received positive response from very few doctors (Rothschuh, 1978, p. 273). 
Daniel Sennert (1572-1637), professor of medicine at the University of Wittenberg, became a mediator between the ideas of Galen and Paracelsus and tried to reconcile among themselves the teachings of Aristotle, Galen, atomistics and Paracelsus. Sennert's views are on the one hand galenic explanation of humoral pathology, yet he also recognised Paracelsus's teaching of the principle of three elements (Debus, 1977, pp. 198-199). His De chymicorum cum Aristotelicis et Galenicis consensu et dissensu, published in 1619, contributed to bringing chemiatry to the attention of university professors. In 1636, he introduced atoms to the elements of Aristotelian elemental matter (Rothschuh, 1978, p. 204ff).

It is also noteworthy that Sennert followed Paracelsus's teaching of illnesses in regard to tartaric illnesses (gall, bladder and kidney stones). Stones develop in the body not due to the effect of the categories warm and cold, but rather these stones may arise from chemical causes as a result of the occurrence of salt as residue.

Sennert denied the doctrine of signatures. Andreas Libavius (1555-1616), one of the most dedicated developers of Paracelsus's theory who supported chemical medicines and the theory of the principle of three elements, was against cosmology and biblical interpretations as well as magic and the teaching of forms (Debus, 1977, p. 202).

Even though Sennert, as a cautious eclectic, did not stress the priority of the teaching of Paracelsus, he nevertheless encountered an aggressive opponent in Johann Freitag (1581-1641), professor at the University of Groningen. $\mathrm{He}$ published a work in Amsterdam in 1636 attacking Sennert's book. It appears that by the time Witte studied at the university, the attitude in the Netherlands was noncommittal towards Paracelsus's teachings of pathology. The influence of Johan Baptista van Helmont, who worked in Flanders and died in 1644, began to emerge only after the posthumous publication of his book in 1648 that stimulated the development of the iatrochemistry trend. The formation of Franciscus le Boe Sylvius's iatrochemistry school of thought occurred in the 1660s and 1670s. Franciscus le Boe Sylvius became professor of medicine at Leiden in 1658. Not a single influential physician associated with the university, however, is known who would have propagated Paracelsus's teachings of illnesses in the Netherlands in the 1640s. Johann Freitag's attacks against Daniel Sennert in the 1630s, however, were not without effect. It appears that Witte's teacher Jan Johannes Walaeus was also rather cautious and hesitant concerning the teachings of Paracelsus. Thus Bernhard Swalve has recorded from his lectures 
that proponents of Paracelsus palm off cure-all medicines through deceit. ${ }^{24}$ True enough, in actual fact, each illness had a specific medicine in the theory of Paracelsus but it was possible to pick out claims to the opposite effect from his contradictory teachings. The negative attitude of Witte's teacher Walaeus regarding Paracelsus's teachings on pathology apparently set the background for Witte. Witte repeatedly expresses his sceptical attitude towards not only the views of the medical authorities of antiquity but also towards the views of Paracelsus. On the one hand, he views the teachings of Galen and Paracelsus as two sects competing against each other and claims to distance himself from both of them. In the foreword to his disputation of 1647 , Witte says this directly (see footnote 26). Different trends that did not at all go hand in hand branched out from the discursive and often contradictory views of Paracelsus: iatroastrology, iatrotheology, iatromagic and iatrochemistry. The teaching of astromedicine saw the causes of illnesses as the effect of the constellation of planets in relation to each other and other such factors. In this regard, the influence of Paracelsus and Robert Fludd was great. Even though the interest of physicians in astromedicine from the viewpoint of the causes of illnesses receded in the latter half of the $17^{\text {th }}$ century, works on that theme were still being written at that time, for instance by Athanasias Kircher or Abdias Trew, professor at Altdorf (Rothschuh, 1978, p. 62ff).

Witte denied the effect of the stars as a cause of dropsy (Witte, 1645) and he also denied the predictions of astrologers concerning the occurrence of the plague.

The essence of iatrotheology is the idea of illness as the consequence of mankind's disobedience and sinfulness before God (Rothschuh, 1978, p. 24). Both Paracelsus and Robert Fludd (1574-1637) developed this old concept (Rothschuh, 1978, p. 64). Witte is cautious in his attitude towards the ideas of the punishment of God. He leaves that to theologians while himself preferring the explanation of natural science (Witte, 1648).

Iatromagic lies in the use of magical ways of thinking and practice in medicine. Magical thinking includes certainty of the existence and influence of direct mysterious forces, which among other things include sympathy and antipathy (Rothschuh, 1978, p. 106ff). The iatromagical concept of medicine based on Agrippa von Nettesheim and Paracelsus was very widespread among doctors throughout the $16^{\text {th }}$ century and it had many proponents in the $17^{\text {th }}$ century

24 Notentur hic obiter Paracelsistarum errores, fraudes \& fuci, qui vel lapidem suum Philosophicum, vel alias, nescio quas Panaceas, Phalejas \& Asas, uti nominant nobis obtrudere volunt, ea spe \& pollicitatione, ac si hisce medicamentis solis omnis in universum affectus, curari \& eradicari possint (Schouten, 1972, p. 255). 
as well. Yet researchers who relied on experiments based on evidence started relating very critically to iatromagic. Consider, for example, Hermann Conring at Helmstedt (Rothschuh, 1978, p. 153) or the scholars who formed the background for Witte's university studies. Thus Cornelis van Hoghelande, a friend of Descartes to whom Witte dedicated his disputation of 1645, expresses a negative attitude towards iatromagical explanations like forms and attributes, antipathies or sympathies, the predestination of nature and secret qualities in the part of his book Cogitationes..., published in 1646, on physiology, dismissing them as pseudo-explanations.

In order to liberate chemistry from occult qualities, Hoghelande suggests the subtle ethereal matter of Descartes instead of Anima mundi (Fuchs, 1992, p. 151). Apparently under the influence of Hoghelande, Witte expressed very nearly the same sentiments in the foreword to his doctoral dissertation in 1648 . He wrote that he was attempting to explain the causes of the plague clearly and penetratingly without the effects of the stars, secret qualities, proprietate et similitudine substantia, idiosyncrasies, sympathies and antipathies, the soul of the world, magnetica ad/.../ctione, and other by ways of listlessness and ignorance. ${ }^{25}$

Thus while Witte had definitely distanced himself from the teaching of four bodily fluids, he had himself taken Paracelsus's teaching of the principle of three elements as his basis that he used as a guide in all three of his disputations. Witte's attitude to the teachings of Paracelsus can be compared to Paracelsus's contemptuous attitude towards Arabian medicine, even though the part of his teachings on alchemy was borrowed precisely from the Arabs. Let me present below characteristic examples of Witte's application of the principle of three elements.

Thus, one component of blood is sulphuric substance that the fire located in the heart uses as its food. The larger the fire is, the less the sulphur is capable of restraining the serum. This kind of burning of sulphur allegedly takes place first and foremost in the case of high fevers. Serum also takes salt with it (Witte, 1645, Thesis 41).

Witte says in his disputation on arthritis that a number of serious illnesses are caused by very stinging salt acrimony. The tartarous part of salt and faeces terrestris are deposited. The corrosive effect of sharp, penetrating salt acridities

25 Haec autem omnia clare et perspicue explicare conatus sum, absque ullis siderum influentiis, occultis qualitatibus, proprietate et similitudine substantiae, idiosyncrasia, sympathiis et antipathiis, anima mundi, magnetica ad Adtracttione, aliisque ignaviae et ignorantiae diverticulis. Sed ubi experientiae medicorum contrariae inter se occurrebant, hanc viam inii, ut, quandoquidem et propria experientia nibil definire possem (Witte, 1648, Introduction). 
is an important cause of arthritis. They damage parts of the body to the extent that even the smallest distension can cause sharp pain (Witte, 1647, Thesis 5). In his disputation on the plague, Witte provides typical recommendations for treatment borrowed from the treatment arsenal of Paracelsus.

If the plague is already within the organism, the salt acrimonies of pestilential virulence that are indivisible, strong and sharp in their shape should be either weakened, that is blunted, or covered by a sticky, oily coating to reduce the strength of its poison. The former case is purely similis contra similem, where poison that causes illness is weakened using strong poison. In this case, a chemical reaction takes place between curative and the poisonous salt, resulting in the depositing of the poison. Poisonous salt particles dissolve into smaller parts and dissipate. In diluted form, they have considerably less effect as poison. The substance of the salts itself does not change in dispersion but their effect decreases considerably. Here Witte had in mind the working out of a specific medicine, expressing the hope that doctors will come up with it. This is a very important line of reasoning from the standpoint of the development of medicine.

The vigorous triumphal progress of this kind of production of chemical medicines, however, lived its own life and was most likely no longer even associated with Paracelsus but rather more with the names of Sennert, Libavius, Croll or Quercetanus.

The laxative effect, or that of inducing vomiting, of these medicines also found support among proponents of Galen's theories. At that time, several wellknown experts in chemical medicine had set themselves up in Amsterdamfor instance Johann Rudolf Glauber or Franciscus le Boe Sylvius, who was associated with Glauber and was later to become a promoter of the trend towards iatrochemistry. It is possible that Witte gained effective knowledge of chemistry from these or other experts in chemistry, which he proficiently used in his disputations. 


\section{Data on Witte's contacts as a doctor with Europe's Republic of Letters as points of reference and on the necessity of searching for his private archive}

Nicolaus Witte was very well off economically on the scale of Riga and was at the tip of the social pyramid. As the archiater of Sweden's royal household, he often had to travel to Stockholm, yet the situation in Livland after the Swedish-Russian War and the plague of 1657 was depressing for Witte. Namely, institutions that brought scholars together in Riga, first and foremost its Gymnasium, had collapsed. It was not until the 1670s that the scholarly environment that was so important for Witte began to recover. As a talented doctor with an investigative spirit, Witte missed not only the learned environment a great deal but also particularly contacts with Europe's Republic of Letters.

He considered it important to keep abreast of the most up-to-date new literature from the world of science, which was becoming ever more lively just then, in the 1660s. Witte's one-time friend Nicolaus Heinsius refers very tellingly to the situation in a letter sent in 1662 to Leiden's professor of medicine Adolph Vorstius, a former teacher of Witte, writing that Witte did not have opportunities to deal with science in that extremely barbaric corner of the world, and thus planned to return to Holland. ${ }^{26}$ Witte tried to keep abreast of newer natural scientific literature from throughout Europe and to this end he tried to make contact with figures in the centres of the Republic of Letters. His connections with old correspondence partners from the years of his university studies as well as new correspondence partners belonging to Europe's Republic of Letters would merit further detailed research, for which numerous publications of correspondence would provide excellent subject matter as primary sources.

We are currently aware of only a few isolated fragments of Witte's communication with centres of learning. Thus it is known that Witte was particularly interested in the newest English natural scientific literature. In order to be able to read that literature, he learned English in addition to Italian and French that he had already previously mastered. Abraham Hill, founding member and treasurer of the Royal Society, which had just been founded, sent him the most recent natural scientific literature on 1663-1669. One of Witte's letters concerning a way of

26 Is /Wittel de lare in Batavos iterum transferendo cogitat, quamquam \& uxore \& dote luculenta auctus praxin feliciter Rigae exerceat, non sine multo emolumento. Studiis hoc a se dari affirmat, \& literarum amori, quas in ultimo Barbariae angulo non nisi eminus colere \& venerari potest. Vellet tamen conditionem qualemcumque offerri, ne privatam vitam cogeretur sequi, \& artis medicae professionem abrumpere per intempestivum otium... (Burman, 1727, p. 794). 
preserving wines from freezing was read out loud at a Royal Society presentation meeting in 1669. This is clearly a classical example of introducing scientific research into practice! (Boas Hall, 1991, pp. 54, 148; Hill, 2010, pp. 207-241) It can be presumed that Jacob Philipp Sachs von Löwenheim (1627-1672) was one of the people who supplied Witte with the latest German scientific literature. Löwenheim was a member of the Academia Naturae Curiosorum (Academy of Sciences Leopoldina) and in 1670 had started publishing Ephemerides Academiae Naturae Curiosorum, the first ever learned journal in the field of medicine and natural history. Upon the publication of his book Gammarologia... in 1665, Witte was one of his congratulators, among whom were also Witte's correspondents: Copenhagen professor Thomas Bartholinus, and Johann Daniel Major (1634-1693), later a professor at Kiel. It is possible that Witte became a correspondent member of the natural scientific society known as Leopoldiana, the oldest German scientific society of that time that continues to operate to this day. Keeping in mind the future research of the activity of Nicolaus Witte, it is noteworthy that he is said to have worked out a medicinal powder (Wittiani pulver), which was apparently valued in Riga as well as abroad. ${ }^{27}$ Pharmacopoeias from that time and letters that Witte sent to scholars could provide some idea of the composition of this medicine and which illness it was used to treat.

Nicolaus Witte left behind an abundance of manuscripts that would be an extremely valuable historical source for researching his work and its background. Witte's correspondence with the physicians and philology enthusiasts of Europe of that time included letters from many of his renowned acquaintances, for instance from Descartes, Gerard Johannes Vossius, Henricus Regius, Thomas Bartolinus and Ole Worm. ${ }^{28}$ No doubt, his album amicorum and possible travel diaries would provide the most information about Witte's circle of friends and about the places where he stayed. Witte also left behind a chest containing manuscripts of his own works, of which some were on philological themes, particularly about loan words from Latin in European languages. Unfortunately, there are no traces of the further fate of Nicolaus Witte's archive.

Considering Witte's communications with people who shaped the field lines

27 In arte autem medica atque chymica quid aesculapius noster valuerit, me quamvis tacente, tota loquitur civitas, Wittiani pulveris nunquam immemor, nec id nobiliores aliorum populorum regiones penitus ignorant (Witte, 1688, p. 5).

28 Quid de fautoribus eius amicisque dicamus, quos, ex locis dissitis, virtute sibi paraverat, et quibuscum de maximi momenti rebus, commercia instituerat literaria? Praeter supra enumeratos, adfuerunt ei Cartesius, Beverovicius, Heurnius, Vossius, Gruterus, Bartholinus, Sachsius, Regius, Kyperus, Wormius, Major, Morhoffius, et quis non inter eruditos seculi huius heroum? Hi summis saepe nostrum ornarunt elogiis, et supra quam dici potest doctrinam in eo omnigenam extulerunt. (Witte, 1688, p. 5) 
of seventeenth-century medicine, the search for his manuscripts would be eminently necessary. Yet to whom could Nicolaus Witte's archive and library have been bequeathed? Witte outlived his wife Gertrud, who died in 1678, his son Johann, who died as a student in 1679, and his daughters Catharina Christina, who died in 1680, and Gertruta Wilhelmine, who died in 1685. His daughters Gertruta and Anna outlived their father. The most likely possessor of the Witte archive could have been the Haltermann family. Namely, Anna, one of Witte's daughters, had married the lawyer Heinrich Haltermann and died in 1703. Their son Justus Johann Haltermann (1689-1738) and grandson Justus Johann (1723-1761) were in the service of the Riga municipal council. It would have been natural for Nicolaus Witte's manuscripts to be bequeathed to the next generation of doctors. Yet, since David Martini, the husband of Nicolaus Witte's second daughter Catharina Christina had already remarried during Nicolaus Witte's lifetime in 1682 and their son Nicolaus Martini was only ten years old at the time of his grandfather's death, it is not likely that Nicolaus Witte's manuscripts found their way into the possession of the Himsel family through Nicolaus Martini's daughter Catharina Christina (died in 1775). The heritage of the physician Nicolaus Himsel, who died early at the age of 35, forms the basis for the current Riga Municipal Museum and his manuscripts are in the Latvian Academic Library. The manuscripts of Nicolaus Witte, however, are not among them. Gertruta Wilhelmine married Riga physician Wilhelm Lange in 1685 but died that very same year (Brennsohn, 1905, p. 262). It appears that the manuscripts of Nicolaus Witte were not in the possession of the BalticGerman families who lived in Riga in the first decades of the $20^{\text {th }}$ century because historian of medicine Isidor Brennsohn and genealogists like Erik Seuberlich, for instance, would have used them as thankworthy source material.

\section{Summary}

In summary let us recognise that Nicolaus Witte von Lilienau from Riga, who was also the municipal physician there in 1652-1688, had studied during most of the ten or so years that he spent abroad in the Netherlands, primarily at the University of Leiden, but also at the universities of Utrecht and Franeker. The universities at Leiden and Utrecht, in particular, developed at that time into strongholds for supporters of Harvey's theory of blood circulation and the philosophy of Descartes, from where by way of those supporters those ideas gradually found acceptance elsewhere as well. Witte was fortunate to have a 
close-up view of the fierce opposition between supporters and opponents of the philosophy of Descartes. Studying at Leiden was not in and of itself a guarantee that all of its students would become enthusiastic supporters of new ideas. The teachings of Galen lived on peacefully in the Faculty of Medicine there as well. Yet lecturers and students of a more inquisitive spirit had the opportunity to arrive at the recognition and adoption of new ideas. Nicolaus Witte was one of those students. Witte defended three disputations, two of which exercitii causa. The first was on abdominal dropsy in 1645 at Leiden, presided over by Johannes Walaeus. The second was on arthritis in 1647 at Franeker, presided over by Johannes Antonides van der Linden. He defended his doctoral dissertation on the plague at Leiden in 1648.

Witte's views on physiology and pathology were pioneering in all of his disputations. Under the apparent influence of his teacher Johannes Walaeus, Witte considered the teaching of blood circulation to be self-evident. The blood circulation system was not the specific object of his research but it is, however, considered as the physiological background in explaining the causes of illnesses. To treat the theory of blood circulation as a matter of fact and a self-evident information tells about a thorough adoption of the theory. Nicolaus Witte is the first doctor in the Baltic region known to have favoured the theory of blood circulation.

Witte's choice of sides was his dedication of his disputation of 1645 to Descartes and his closest friends and public supporters. This was a very bold move considering the conditions of those times. Yet this probably did not derive so much from Witte's passion for philosophy but rather from the fact that all those individuals were at the same time also supporters of the theory of blood circulation.

Yet in choosing his scientific method, Witte appeared to be guided by the rationalist philosophy of Descartes: theory and hypotheses for ascertaining the causes of illnesses are derived as a result of thought processes. The validity of such theory and hypotheses then had to be verified by experiment. This is the source of Witte's negative attitude towards authorities considered to be infallible, whether they be authors from antiquity or more recent authors. Thus he distanced himself from the teachings of both Galen and Paracelsus as the teachings of rival sects. Witte distanced himself in his disputations from both Galen's teaching of four bodily fluids, which was still widely accepted at that time, and the teaching of the movement of blood and of the liver as the centre for producing blood. Witte also denied the concepts of iatroastrology, iatromagic and iatrotheology associated 
primarily with the teachings of Paracelsus. Yet he did espouse the principle of three elements and the teaching of chemiatry. Witte's progressiveness was also expressed in therapy: he did not consider miasmas to be the causes of plague but rather minute chemical poison atoms. Witte proposed alterant medicines for inhibiting the sharpness and penetrative capacity of those acrimonies of pestilential virulence in the hope that these will be developed in the future.

As the municipal physician of Riga and the personal physician of the King of Sweden, Witte's social position in Livland was the highest that was possible.

Considering Witte's openness to new physiological ideas in his time as a student and especially his espousal of the theory of blood circulation, and the fact that he was one of the people who influenced medical life in Riga the most in the latter half of the $17^{\text {th }}$ century, it would certainly be necessary to research his medical views and their practical application in the course of his work as Riga's municipal physician. Witte's work in implementing measures to combat the plague of 1657, for which he was ennobled as a member of the Swedish nobility, would be a particularly interesting topic of investigation.

Since Nicolaus Witte's medical views evolved through interaction with many of the scholars of that time, it would be very important to investigate how he related to the Republic of Letters at that time. It is definitely known that Witte communicated with the newly founded Royal Society and that he was very much interested in the latest English natural scientific literature.

Last but not least, the appreciation of the disputations that Nicolaus Witte defended in the Netherlands and also the disputation that his colleague Johannes Michel defended at Königsberg as exceedingly valuable sources for the reception of the theory of blood circulation could inspire researchers who consider disputations from the early modern era to be important sources for the history of science while also arousing the interest of people who consider old disputations to be nothing more than useless wastepaper containing scholastic balderdash. 


\section{References}

Ackerknecht, E. H. (1970), Therapie von den Primitiven bis zum 20. Jahrhundert, Stuttgart: Ferdinand Enke Verlag.

Bartholinus, T. (1663-1667), Epistolarum Medicinalium Centuria 1-4, Copenhagen.

Berkel, K; van Helden, A. \& van Palm, L., eds. (1998), A History of Science in the Netherlands: Survey, Themes and Reference, Leiden: Brill.

Beukers, H. (1987-1988), 'Clinical Teaching in Leiden from the Beginning to the End of the Eighteenth Century,' Clio Medica, vol. 21, nos. 1-4, pp. 139-151.

Boas Hall, M. (1991), Promoting Experimental Learning: Experiment and the Royal Society, 1660-1727, Cambridge: Cambridge University Press.

Brennsohn, I. (1905), Die Aerzte Livlands von den ältesten Zeiten bis zur Gegenwart. Ein biographisches Lexikon nebst einer historischen Einleitung über das Medizinalwesen Livlands, Riga: E. Bruhns.

Burman, P. (1727), Sylloges epistolarum a viris illustribus scriptarum, vol. 2. Leidae: Apud Samuelem Luchtmans.

Costerus, J. (1645), Disputationem inauguralem medicam de variolis \& morbillis Sine praeside, publicae filiatron censurae submittit Johannes Costerus, Gadebuscensis Megapolitanus. Ad diem 22. Maii, horis locoque solitis, Lugduni Batavorum: officina F. Hegeri. The British Library exemplar.

Debus, A. G. (1977), Chemical Philosophy: Paracelsian Science and Medicine in the Sixteenth and Seventeenth Centuries, vol. 1, New York: Science History Publications, a division of Neale Watson Academic Publications.

Diemerbroek, Y. (1646), De peste libri quatuor truculentissimi morbi historiam ratione \& experimentia confirmatam exhibentes, Arnhem: ex officina Joannis Iacobi.

Enzyklopädie Medizingeschichte (2005), ed. by W. E. Gerabek, B. D. Haage, G. Keil \& W. Wagner, Berlin \& New York: De Gruyter.

Freudenhammer, G. S. (1645), Disputatio medica inauguralis de hydrope Pro gradu doctoratus et privilegiis medicinae consequendis, sine preside publice defendet... Georgius Siegefridus Freudenhammer ad diem 19. Maii horis locoque solitis, Lugduni Batavorum: officina Johannis Maire. The British Library exemplar.

Friedenthal, M. (2014), 'Sissejuhatus Meditatsioonidesse', [In Estonian; Introduction into Meditations] in Rene Descartes: Meditatsioonid esimesest filosoofiast [Rene Descartes: Meditations on First Philosophy], Tartu: Ilmamaa, pp. 7-24.

Fuchs, T. (1992), Die Mechanizierung des Herzens. Harvey und Descartes - der vitale und der mechanische Aspekt des Kreislaufs, Frankfurt am Main: Suhrkamp Verlag.

Harskamp, J. (1997), Dissertatio Medica Inauguralis: Leyden Medical Dissertations in the British Library, 1593-1746: Catalogue of a Sloane-inspired collection, comp. by J. Harskamp, London: The Wellcome Institute for the History of Medicine. 
Helk, V. (1987), Dansk-norske studierejser fra reformationen til enevaelden 1536-1660 med en matrikel over studerende i udlandet, Odense University Studies in History and Social Sciences, vol. 101, Odense: Odense University Press.

Hiiemäe, R. (2003), 'Katkupärimuse kujunemist mõjustavatest teguritest,' [On factors influencing the evolution of plague lore] Mäetagused, vol. 22, pp. 80-94.

Hill, A. (2010), Familiar Letters which passed between Abraham Hill, Esq. ... and several eminent and ingenious persons of the last century, Farmington Hills, MI: Gale ECCO Print Editions.

Kelly, W. A. (2006), A Catalogue of Seventeenth Century Medical and Scientific Imprints in Edinburgh Libraries. Series 2: Low Countries Imprints, vol. 1, Edinburgh: Edinburgh University Library, Royal College of Surgeons of Edinburgh, Royal Botanic Garden, Royal Medical Society.

Komorowski, M. (2011), 'Bibliotheken,' in U. Rasche (ed.) Quellen zur frühneuzeitlichen Universitätsgeschichte: Typen, Bestände, Forschungsperspektiven, Wolfenbütteler Forschungen 128, Wiesbaden: Harrassowitz Verlag, pp. 55-82.

Lieburg, M. I. (1982), 'Deutsche Studenten in Leiden (1628-1688) und die Einführung der Kreislauflehre William Harvey's in Holland,' in M. I. Lieburg \& R. Töllner (eds.) Deutsch-Niederländische Beziehungen in der Medizin des 17. Jahrhunderts. Vorträge des deutsch-niederländischen Medizinhistorikertreffens 1981, Amsterdam: Rodopi, pp. 39-76.

Lindeboom, G. A. (1970), 'Medical Education in the Netherlands 1575-1750,' in C. D. O'Malley (ed.) The History of Medical Education, Berkeley \& Los Angeles: University of California Press, pp. 201-216.

_ (1975), 'Dog and Frog. Physiological Experiments at Leiden during the Seventeenth Century,' in T. H. Lunsingh Scheurleer \& G. H. M. Posthumus Meyjes (eds.) Leiden University in the Seventeenth Century. An Exchange of Learning, Leiden: E. J. Brill, pp. 279-293.

- (1978), Descartes and Medicine, Amsterdam: Rodopi.

(1985), 'Johannes Antonides van den Linden (1609-1664), medisch hoogleraar te Franeker en te Leiden. Zijn betekenis voor de Friese hogeschool,' in G. T. Jensma et al. (eds.) Universiteit te Franeker 1585-1811. Bijdragen tot de geschiedenis van de Friese hogeschool, Leeuwarden: Fryske Academy, pp. 356-370.

_ (1943), Paracelsismen i Sverige till 1600-talets midt, Uppsala: Almqvist \& Wiksells boktryckeri $\mathrm{AB}$.

Lindroth, S. (1957), 'Harvey, Descartes, and Young Olaus Rudbeck,' Journal of the History of Medicine and Allied Sciences, vol. 12, pp. 209-219.

Losell, Ioh. (1639), De podagra tractatus: morbi huius indolem et curam diligenter exponens, Lugduni Batavorum: ex officina Ioannis Maire.

Mani, N. (1961), 'Darmresorption und Blutbildung im Lichte der experimentellen Physiologie des 17. Jahrhunderts,' Gesnerus, vol. 18, pp. 85-146. 
(1976), 'Naturwissenschaftlich-biologische Grundlagenforschung in der Medizin des 17. Jahrhunderts,' Medizinhistorisches Journal, vol. 11, pp. 181-205.

Marti, H.-P. (2011), 'Dissertationen,' in U. Rasche (ed.) Quellen zur frühneuzeitlichen Universitätsgeschichte: Typen, Bestände, Forschungsperspektiven, Wolfenbütteler Forschungen, vol. 128, Wiesbaden: Harrassowitz Verlag, pp. 293-314.

Preiser, G. (1969), 'Zur Hippokratesauffassung des Johannes Antonides van der Linden,' Medizinhistorisches Journal, vol. 4, pp. 305-313.

Recke, J. F. \& Napiersky, K. E. (1832), Allgemeines Schriftsteller-und Gelehrten-Lexikon der Provinzen Livland, Esthland und Kurland, vol. 4, Mitau: J. Fr. Steffenhagen \& Sohn.

Rosner, E. (1969), 'Die Bedeutung Hermann Conrings in der Geschichte der Medizin,' Medizinhistorisches Journal, vol. 4, pp. 287-304.

Rothschuh, K. E. (1957), "Die Entwicklung der Kreislauflehre im Anschluß an William Harvey: Ein Beispiel der 'autokatalytischen Problementfaltung' in den Erfahrungswissenschaften," Klinische Wochenschrift. Organ der Gesellschaft Deutscher Naturforscher und Ärzte, vol. 35, no. 12, pp. 605-612.

(1968), Physiologie. Der Wandel ihrer Konzepte, Problemen und Methoden vom 16. bis 19. Jahrhundert, Freiburg \& München: Karl Alber.

— (1969), Physiologie im Werden, Stuttgart: Gustav Fischer Verlag.

(1978), Konzepte der Medizin im Vergangenheit und Gegenwart, Stuttgart: Hippokrates Verlag.

Ruestow, E. (1973), Physics at Seventeenth and Eighteenth-Century Leiden: Philosophy and the New Science in the University, The Hague: Martinus Nijhoff.

Schouten, J. (1972), Johannes Walaeus. Zijn betekenis voor de verbreiding van de leer van de bloedsomloop, Assen: Van Gorcum and comp.

_ (1974), 'Johannes Walaeus... (1604-1649) and His Experiments on the Circulation of the Blood,' Journal of the History of Medicine and Allied Sciences, vol. 29, pp. 259-279.

Tering, A. (1996), 'Descartes in Swedish Livonia. On the Arrival of Cartesian Ideas in Estonia and Livonia, the Baltic Provinces of Sweden, in the $17^{\text {th }}$ Century and the Beginning of the $18^{\text {th }}$ Century,' in Mundus librorum. Essays on Books and the History of Learning, Publications of the Helsinki University Library, vol. 62, Helsinki: Helsinki University Library, pp. 135-152.

(2012), 'Zur frühen Rezeption von Harveys Theorie des Blutkreislaufs im deutschen Sprachraum: Eine apologetische Disputation in Königsberg aus dem Jahre 1651,' in R. B. Sdzuj, R. Seidel \& B. Zegowitz (eds.) Dichtung-Gelehrsamkeit - Disputationskultur. Festschrift für Hanspeter Marti zum 65. Geburtstag, Köln \& Weimar: Böhlau Verlag, pp. 461-481.

Trevisani, F. (2011), Descartes in Deutschland: die Rezeption des Cartesianismus in den Hochschulen Nordwestdeutschlands, Wien, Zürich \& Berlin: Lit-Verlage. 
UBL (1650), 'Amsterdam pridie cal. maji /30.4/ 1650', Brieven van Nicol. Witte aan Nicolaas Heinsius (1620-1681), BUR F 6a, Leiden University Library.

Verbeek, T. (1992), Descartes and the Dutch Early Reactions to Cartesian Philosophy, 1637-1650, Carbondale: Southern Illinois University Press.

Vermij, R. (2002), The Calvinist Copernicans. The reception of the new astronomy in the Dutch republic, 1575-1750, History of Science and Scholarship in the Netherlands, vol. 1. Retrieved from http://www.dwc.knaw.nl/wp-content/HSSN/2002-1-VermijCalvinist\%20Copernicans.pdf [accessed Oct 2014]

de Wale, J. (1942), Zwei Briefe über die Bewegung des Chylus und Blutes an Thomas Bartholin, Sohn des Caspar 1640. Übersetzt und erläutert von Bernward Joseph Gottlieb, Leipzig: Verlag von Johann Ambrosius Barth.

Witte, H. (1688), Lessum funebrem, cum vir quondam nobilissimus etc. Dominus Nicol. Witte a Lilienau, Med. Dr. celeberrimus, sacrae Regiae Maiest. Sueciae per plurimos annos archiater, inque patria physicus primarius ac longe meritissimus, mortalitatem exueret, et ad vitam transiret meliorem, moerens lugensque patrueli desideratissimo facere conabatur M. Henningus Witte eloq. Et histor. PP. Rigae: Georgii Matth. Nölleri.

Witte, N. (1648), De pestilentia, ex auctoritate... ad d... ad diem 25. Novembris, loco et horis statutis disputabit Nicolaus Witte, Riganus Livo, Honores Medicinae Doctorales publica solennitate imperaturis, Lugd. Batavorum: Ex chalcographeo Philippi de Croi. The British Library exemplar.

Witte, N. \& van der Linden, J. A. (1647), Privata suae meditationes de causis arthritidis praesente Deo O.M. praeside Johannes Antonides van der Linden, anat. et bot. prof. publicae censura subiicit resp. Nicolaus Witte, riganus livo, Franekerae: Uldericus Balck. The SUB Göttingen exemplar.

Witte, N. \& Walaeus, J. (1645), Hydrops ascites ... praes. Joannis walaei ... ad disputandum propositus a respondente Nicolao Witte Riga Livono ad diem 19. Julii., Lugduni Batavorum: In chalcographeo Francisci Hegeri. The SUB Göttingen exemplar.

Arvo Tering received his PhD degree in history from the University of Tartu. He is senior research fellow at the Tartu University Library. Arvo Tering has been exploring for links between European universities and Baltic area in the early modern period, focusing on the education of Baltic students at European universities and medical education of Baltic physicians in Europe as well reception of new doctrines of medicine and natural sciences (Harvey, Descartes, Copernicus) by Baltic scholars. 